\title{
Evolution of the Astonishing Naica Giant Crystals in Chihuahua, Mexico
}

\author{
Iván Jalil Antón Carreño-Márquez ${ }^{1}$ D , Isaí Castillo-Sandoval ${ }^{2}$, Bernardo Enrique Pérez-Cázares ${ }^{3}$, \\ Luis Edmundo Fuentes-Cobas ${ }^{2}{ }^{\mathbb{D}}$, Hilda Esperanza Esparza-Ponce ${ }^{2} \mathbb{D}$, Esperanza Menéndez-Méndez ${ }^{4}$, \\ María Elena Fuentes-Montero ${ }^{3}$ (D) and María Elena Montero-Cabrera ${ }^{2, *(\mathbb{D})}$
}

1 Department of Engineering, Universidad La Salle Chihuahua, Chihuahua 31625, Mexico; 10307@ulsachihuahua.edu.mx

2 Department of Environment and Energy, Centro de Investigación en Materiales Avanzados, Chihuahua 31136, Mexico; isai.castillo@cimav.edu.mx (I.C.-S.); luis.fuentes@cimav.edu.mx (L.E.F.-C.); hilda.esparza@cimav.edu.mx (H.E.E.-P.)

3 Department of Computational Chemistry, Universidad Autónoma de Chihuahua, Chihuahua 31125, Mexico; bernardoperez.cazares@gmail.com (B.E.P.-C.); mfuentes@uach.mx (M.E.F.-M.)

4 Department Physicochemical Assays, Instituto Eduardo Torroja de Ciencias de la Construcción, 28033 Madrid, Spain; emm@ietcc.csic.es

* Correspondence: elena.montero@cimav.edu.mx

check for updates

Citation: Carreño-Márquez, I.J.A.; Castillo-Sandoval, I.; Pérez-Cázares, B.E.; Fuentes-Cobas, L.E.; EsparzaPonce, H.E.; Menéndez-Méndez, E.; Fuentes-Montero, M.E.; MonteroCabrera, M.E. Evolution of the Astonishing Naica Giant Crystals in Chihuahua, Mexico. Minerals 2021, 11, 292. https://doi.org/10.3390/ $\min 11030292$

\section{Academic Editors: Thomas N.}

Kerestedjian, Tomasz M. Stawski and Alexander E. S. Van Driessche

Received: 27 December 2020

Accepted: 6 March 2021

Published: 11 March 2021

Publisher's Note: MDPI stays neutral with regard to jurisdictional claims in published maps and institutional affiliations.

Copyright: (c) 2021 by the authors. Licensee MDPI, Basel, Switzerland. This article is an open access article distributed under the terms and conditions of the Creative Commons Attribution (CC BY) license (https:// creativecommons.org/licenses/by/ $4.0 /)$.
Abstract: Calcium sulfate $\left(\mathrm{CaSO}_{4}\right)$ is one of the most common evaporites found in the earth's crust. It can be found as four main variations: gypsum $\left(\mathrm{CaSO}_{4} \cdot 2 \mathrm{H}_{2} \mathrm{O}\right)$, bassanite $\left(\mathrm{CaSO}_{4} \cdot 0.5 \mathrm{H}_{2} \mathrm{O}\right)$, soluble anhydrite, and insoluble anhydrite $\left(\mathrm{CaSO}_{4}\right)$, being the key difference the hydration state of the sulfate mineral. Naica giant crystals' growth starts from a supersaturated solution in a delicate thermodynamic balance close to equilibrium, where gypsum can form nanocrystals able to grow up to 11-12 m long. The growth rates are reported to be as slow as $(1.4 \pm 0.2) \times 10^{-5} \mathrm{~nm} / \mathrm{s}$, taking thousands of years to form crystals with a unique smoothness and diaphaneity, which may or may not include solid or liquid inclusions. Conservation efforts can be traced back to other gypsum structures found prior to Naica's. Furthermore, in the last two decades, several authors have explored the unique requirements in which these crystals grow, the characterization of their environment and microclimatic conditions, and the prediction of deterioration scenarios. We present a state-of-the-art review on the mentioned topics. Beyond the findings on the origin, in this work we present the current state and the foreseeable future of these astounding crystals.

Keywords: Naica; gypsum; giant crystals; nucleation

\section{Introduction}

Giant crystals are rare spectacles and can only be observed in unique places around the globe. Crystals of different proportions have been reported. A beryl, $\mathrm{Be}_{3} \mathrm{Al}_{2}\left(\mathrm{Si}_{6} \mathrm{O}_{18}\right)$, from Madagascar is one of the most outstanding examples with $18 \mathrm{~m}$ long, $3.5 \mathrm{~m}$ diameter, and an estimated mass of 380,000 kg [1]. The Naica giant crystals, in Northern Mexico, are probably the largest and most impressive gypsum $\left(\mathrm{CaSO}_{4} \cdot 2 \mathrm{H}_{2} \mathrm{O}\right)$ crystals on Earth.

Among the variety of minerals found in nature, sulfates are ubiquitous. Calcium sulfate $\left(\mathrm{CaSO}_{4}\right)$ and its various hydrated forms are widely distributed over the earth's crust, absent only in volcanic regions. It has been in use by humans since the third millennium before our era [2]. Gypsum $\left(\mathrm{CaSO}_{4} \cdot 2 \mathrm{H}_{2} \mathrm{O}\right)$ is the main constituent of the White Sands dunes in New Mexico [3], while bassanite $\left(\mathrm{CaSO}_{4} \cdot 0.5 \mathrm{H}_{2} \mathrm{O}\right)$ was found in Mount Vesuvius, Italy, for the first time [4]. Both phases have been detected in some regions of Mars by independent teams [5,6]. Gypsum crystals of exceptional size can be found in the Debar mine (Macedonia), which houses gypsum crystals up to seven meters long in caves near the surface. They remain at room temperature and are surrounded by hydrothermal puddles [7]. These conditions resemble those found in Naica. There is also an old mine 
in Segobriga, Spain, where Romans obtained big gypsum crystals. It was employed as window material before the technology to produce flat glass was available [8]. The Chilean mine of El Teniente in Rancagua hosts euhedral gypsum crystals of $>4 \mathrm{~m}$ [9]. Compared with Naica, these crystals are smaller but chemically similar.

The efforts to describe the structural variants, together with growth, and precipitation of calcium sulfate date back to the beginning of the 20th century [10]. In particular, growth kinetics and mechanisms for the precipitation of calcium sulfate as selenite, a transparent gypsum habit, have been established in [11-13]. It has also been ascertained that the hydration of anhydrite $\left(\mathrm{CaSO}_{4}\right)$ is a crucial factor in the crystallization of selenite [14]. Its dehydration in the presence of carbon dioxide $\left(\mathrm{CO}_{2}\right)$ has been studied to understand its phase transitions, which are attributable to the better solubility or water in carbon dioxide $\left(\mathrm{CO}_{2}\right)$ than in air [15].

The present contribution offers a comprehensive review of meaningful work towards understanding the evolution of the astonishing Naica crystals in Chihuahua, Mexico.

\section{About Naica}

Naica is a town situated in the south-center region of Chihuahua State, in Saucillo municipality (Figure 1). It is located at $27^{\circ} 51^{\prime} 20^{\prime \prime} \mathrm{N}, 105^{\circ} 27^{\prime} 00^{\prime \prime} \mathrm{E}$ coordinates, at $1330 \mathrm{~m}$ of altitude over sea level. Its mean temperature is $18^{\circ} \mathrm{C}$, with some sporadic snow in winter. Annual precipitation is about $200-400 \mathrm{~mm}$, and it is considered to be scarce.

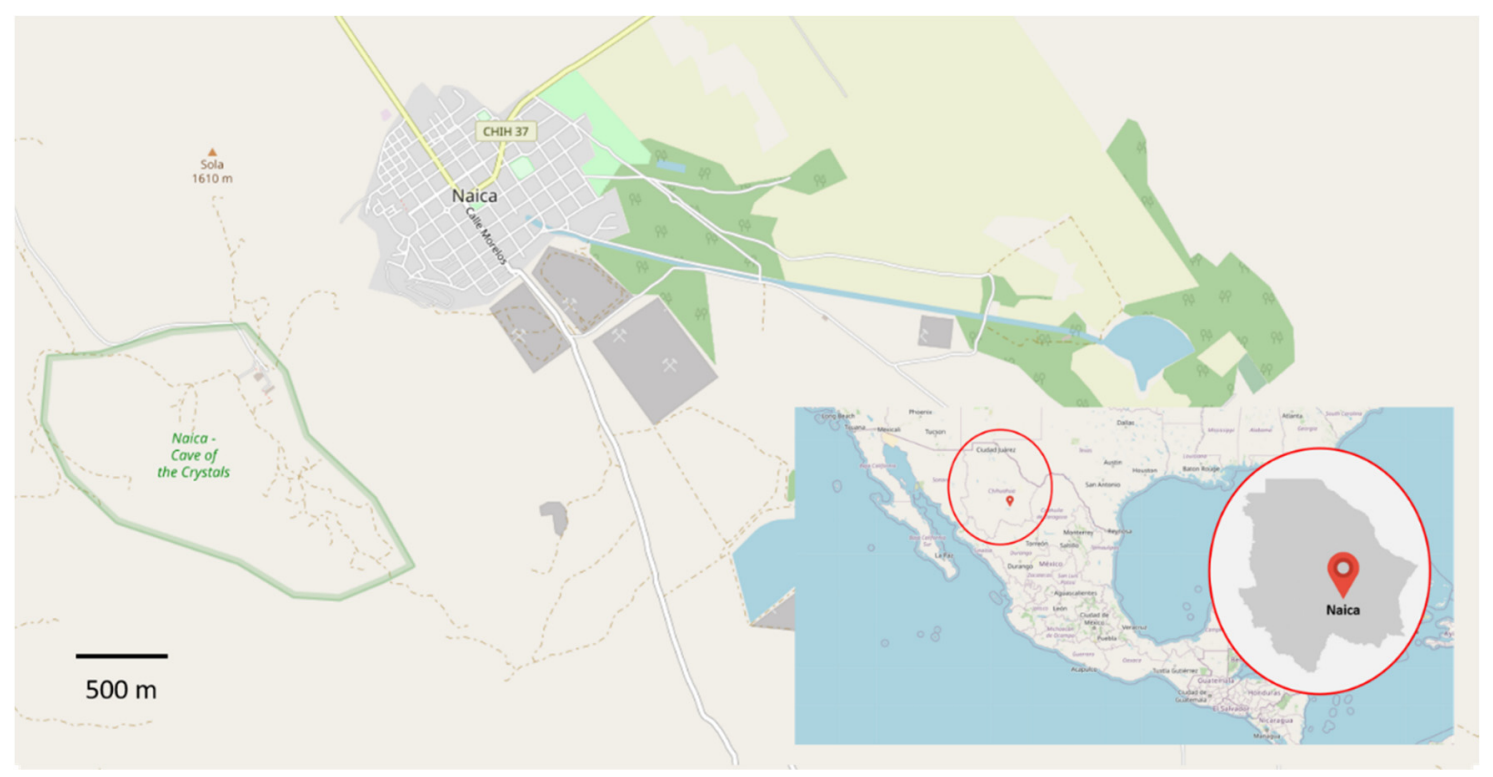

Figure 1. Naica, Chihuahua, Mexico. On the left (in green), the size of the mine can be compared with the town itself. Adapted with an Open Data Commons Open Database License (ODbL). @ OpenStreetMap contributors.

Mining is Naica's primary economic activity since the arrival of the first settlers in 1794. Some minerals present in the zone are quartz, calcite, and silica [16], while relevant metals are lead, zinc, and silver.

The geology of Naica consists of an Early Cretaceous carbonate sequence, composed mainly of limestone as well as marl and dolomite stones in minor quantities. The recrystallization caused by late felsic intrusions brought the thermal reactions needed to drive the presence of the metals $(\mathrm{Ag}-\mathrm{Pb}-\mathrm{Zn})$, and therefore the ore deposits in this mining district. The ore source was produced by a sub horizontal $\left(\sim 20^{\circ}\right)$ batholith-size intrusive magma body located $1000 \mathrm{~m}$ under the surface [17]. Nevertheless, it has been suggested that the concentration of several elements dissolved in Naica's water has variated over the centuries [18] along with the temperature of the fluids. Three different stages of development can be distinguished, one with temperatures from 500 to $680^{\circ} \mathrm{C}$ and high salinity, a second 
stage with temperatures from 240 to $490^{\circ} \mathrm{C}$, and a third one when the fluids lowered their temperature from 119 to $379^{\circ} \mathrm{C}$. These temperature variations led to the development of calcite, quartz, and anhydrite deposits [19].

The structural geological complexity of the mountainous system where the Naica Mine is located has been extensively studied [16]. The area is formed by three minor mountain ranges. They constitute an extensive elongated topographic dome, in the NW-SE direction, containing a series of regional fractures and faults [20]. The mine opens at $1385 \mathrm{~m}$ over sea level in the northern flank of the Naica mountain range. The different stages of Naica's development have been controlled by a thermal aquifer over thousands of years. This evolution led to the formation of fractures where selenite crystals have been able to grow. Several caves containing selenite crystals have been found due to mining activities, being the first discovered in the early 20th century. Among the caves, four stand out: "Cueva de las espadas" (Swords Cave), "Cueva de los cristales" (Crystal Cave), "Ojo de la Reina" (Queen's Cave), and "Cueva de las velas" (Sails Cave) [19]. A cross-section of the complex is represented in Figure 2.

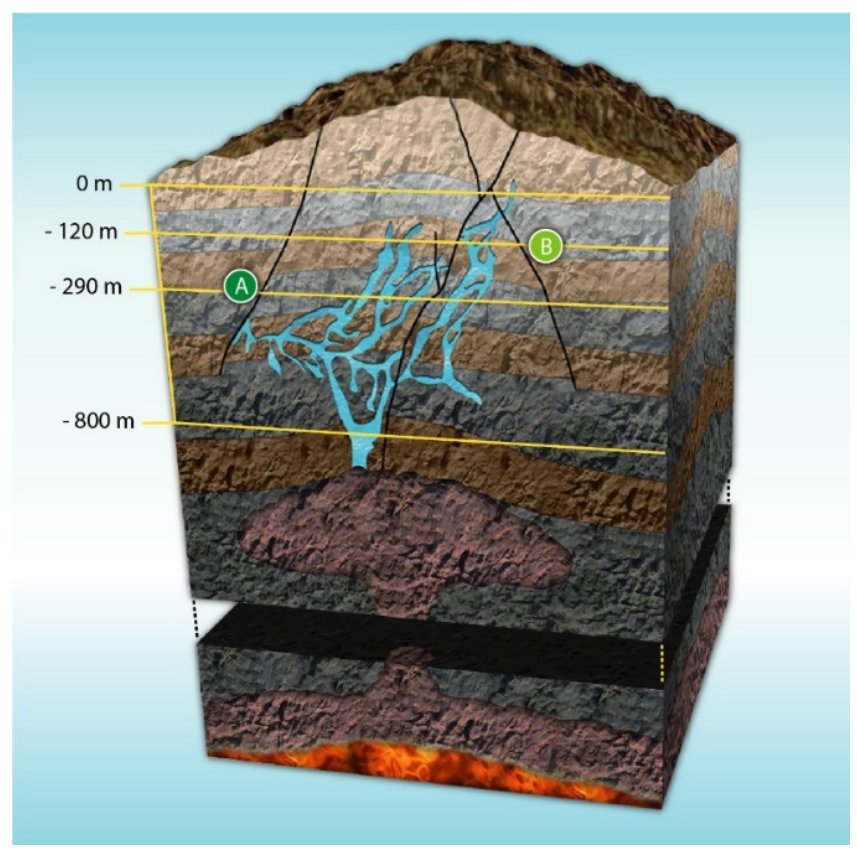

Figure 2. Cross-section of Naica's complex. (A) Crystal Cave and (B) Swords Cave. Adapted and published under a Creative Commons License https:/ / creativecommons.org/licenses/by-nc/4.0/.

\subsection{Water in Naica}

The water in Naica comes from two sources: meteoric infiltrations and magmatic bodies [21]. The region, which serves as a drainage basin, leads much precipitation into the subsurface [22]. Naica aquifer consists of a carbonate sequence up to $3000 \mathrm{~m}$ deep [23] and it has been suggested that, in addition to precipitation, the aquifer could be feed in small amounts by the nearby rivers Conchos and San Pedro [24].

Nowadays, underground water presents a temperature gradient that ranges between 50 and $60{ }^{\circ} \mathrm{C}$. The deep circulation of meteoric water has a $\mathrm{pH}$ of about 7.3 and approximately 300 ppm of total solids dissolved [25]. The current composition of this water is presented ins Table 1 [26].

Different hydrothermal compositions, which include $\mathrm{Mg}, \mathrm{Na}, \mathrm{K}$, and $\mathrm{Sr}$ in addition to $\mathrm{Ca}$ and S [27], have been characterized, suggesting that at least three different compositions have been present in Naica water evolution [18]. The hydrological behavior was fundamental to the development of the conditions in which the giant crystals later grew, since a stable composition of water is mandatory for a constant precipitation rate of calcium sulfate during crystallization [28]. 
Table 1. Current composition of Naica water.

\begin{tabular}{cc}
\hline Solute & Concentration (ppm) \\
\hline Calcium & 1300 \\
Magnesium & 450 \\
Sodium & 100 \\
Chlorine & 51 \\
Silicon & 25 \\
Bicarbonates & 80 \\
Carbonates & 0 \\
Hydroxides & 0 \\
Sulfates & 1715 \\
\hline
\end{tabular}

The calcium sulfate concentration in Naica's water is close to both gypsum and anhydrite's solubility, which is approximately $0.210 \mathrm{~g}$ of $\mathrm{CaSO}_{4}$ per $100 \mathrm{~g}$ of water in a $40-50{ }^{\circ} \mathrm{C}$ range [29]; being the difference within the error range of the used analytic techniques. Trace elements and isotope studies in "Cueva de los cristales" speleothems suggest that water circulation has varied between the last glaciation, $57 \mathrm{ka}$ ago, and the Holocene in periods from $14.5 \pm 4$ to $7.9 \pm 0.1$ and after $7.9 \pm 0.1 \mathrm{ka}$ [23]. The study of these speleothems via U-Th dating allows estimating the phreatic level oscillations during the growth of the crystals [30]. Other isotopes and trace elements suggest that the more significant recharge of the aquifer took place during the last glaciation [28].

It is estimated that "Cueva de los cristales" was underwater at least until 1976, as its natural level would be around 130 to $140 \mathrm{~m}$ below the mine entrance. Then, water started to be extracted at a rate that reached $55 \mathrm{~m}^{3} / \mathrm{min}$ in 2012 to exploit deep ore bodies [31]. In January 2015, a rise in the phreatic level stopped exploration and exploitation of the mine.

\subsection{Crystals}

The first description of giant gypsum crystals in Naica dates to 1912 [32]. It was in 1927 that William Foshag described for the first time the "Cueva de las espadas" in the American Mineralogist journal. This cave is located at $120 \mathrm{~m}$ under the main entrance of the mine, and it is described by the author as "marvelously beautiful" [33]. Today, the cave's walls are utterly crowded with small crystalline gypsum structures of several centimeters in length with solid and liquid inclusions [34,35].

In the last decade, some efforts have contributed to deciphering the growth of Naica crystals. In 2010, the first multidisciplinary endeavor was carried out by "La Venta Exploration Team" [36] based on the mechanism proposed by García-Ruiz and later, by Otálora and García-Ruiz, to explain the slow growth of the giant crystals. According to this process, which the authors have called "self-feeding", the water in the system is at a temperature slightly lower than that of equilibrium between anhydrite and gypsum, $\left(53-58^{\circ} \mathrm{C}\right)$, slowly dissolving the abundant hydrothermal and sedimentary anhydrite in the "Cueva de los cristales" [31,37]. The thermal conditions in which these structures have evolved have also been analyzed, putting into perspective the difficulty for these scenarios to be repeated somewhere else in the world [27]. "Cueva de las velas" structures, derived from the cave's new particular hydric conditions, have been studied by Bernabei, Forti and Villasuso. They describe an atypical "sail" type growth, as seen in Figure 3, in which, by capillarity, the calcium sulfate has been deposited on filaments protruding from its mother structure [38].

The variety of studies made in Naica includes the identification of biological entities present in the cave system. Bacteria have been found in different spots, such as crystals, iron oxide crusts and hot springs, being Firmicutes, Alphaproteobacteria, Betaproteobacteria and Gammaproteobacteria the ones present in the mentioned substrates. Some of these organisms have the ability to precipitate calcium carbonate [39]. Clay samples have been taken from cracks located between 700 and $760 \mathrm{~m}$, and in the giant selenite crystals fluid inclusions. In these places, thermophilic microorganisms, such as Thaumarchaeota chemolithoautotrophs, have been isolated. The adaptive capacity of these creatures is 
remarkable since there is low biomass availability [40]. Microbial communities are likely to be autochthonous from Naica, while some could have been introduced by human activities [39]. Moreover, ancient pollen from woody plants, herb plants, and spores has been found within the crystals. It is suggested that the pollen was transported into the cave by underground water streams $[35,41]$.

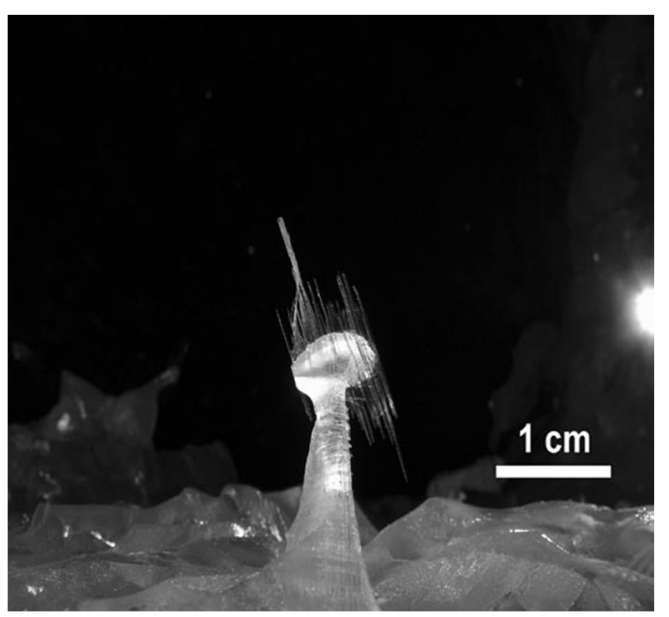

Figure 3. Atypical growth in "Cueva de las velas". Figure reproduced from Bernabei et al. (2007) [38] and published under a Creative Commons License https:/ / creativecommons.org/licenses/by-nc/4.0/.

Since 2000 new caves with giant gypsum crystals have been found in Naica's mining complex. These caves are $290 \mathrm{~m}$ under the main entrance, being "Cueva de los cristales" the most famous due to its $11 \mathrm{~m}$ long crystals, as shown in Figure 4.

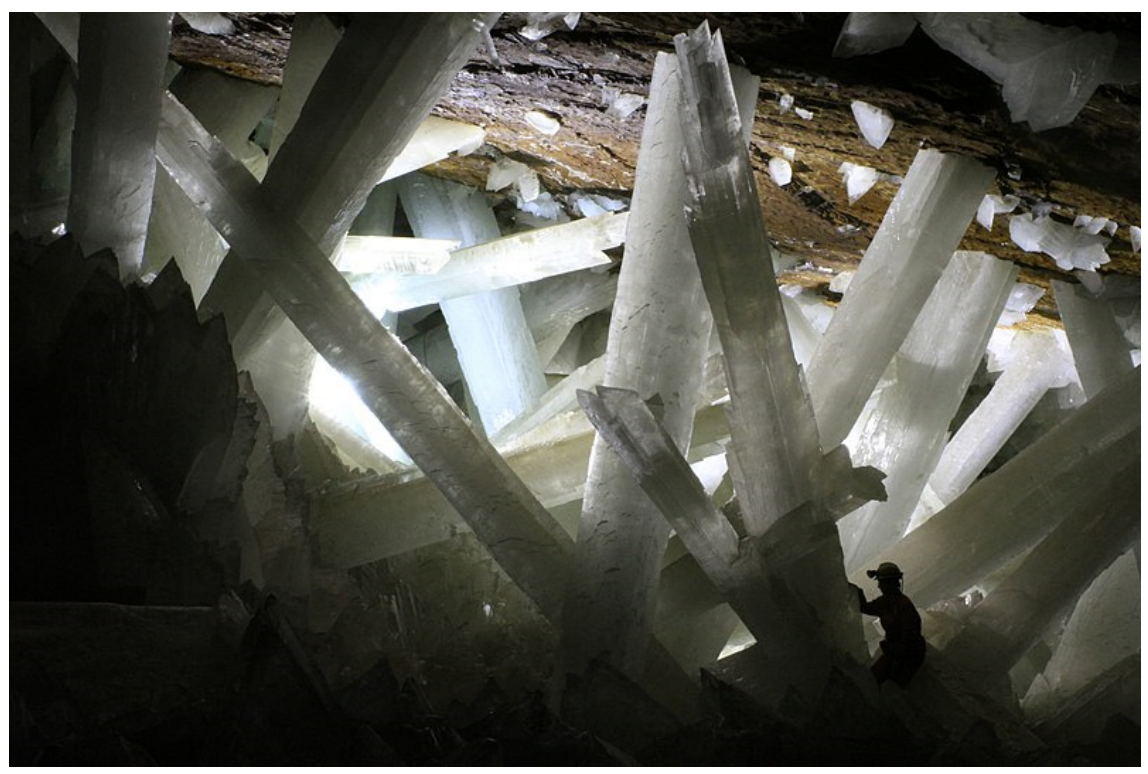

Figure 4. Gypsum crystals from the Naica mine (Person as scale reference). Photo taken by Van Driessche (2010) [12] and published under a Creative Commons License https:/ / creativecommons. org/licenses/by-nc/4.0/.

"Cueva de los cristales" and "Cueva de las espadas" are separated by approximately $170 \mathrm{~m}$ in the vertical axis and $1000 \mathrm{~m}$ horizontally, as seen in Figure 2. 


\section{About Calcium Sulfate as a Crystal}

Five variants of calcium sulfate are known depending on its hydration state: anhydrite $\left(\mathrm{CaSO}_{4}\right) \mathrm{I}$, II and III, hemianhydrite or, as it is geologically known, bassanite $\left(\mathrm{CaSO}_{4} \cdot \frac{1}{2} \mathrm{H}_{2} \mathrm{O}\right)$, and gypsum $\left(\mathrm{CaSO}_{4} \cdot 2 \mathrm{H}_{2} \mathrm{O}\right)$ [14]. The following chemical reaction governs the calcium sulfate crystallization in the form of gypsum:

$$
\mathrm{Ca}^{2+}+\mathrm{SO}_{4}{ }^{2-}+2 \mathrm{H}_{2} \mathrm{O} \rightarrow \mathrm{CaSO}_{4} \cdot 2 \mathrm{H}_{2} \mathrm{O}
$$

Different habits can be found in nature, such as alabaster, crystalline gypsum, desert rose, or gypsum sand. These can be seen in Figure 5. The differences between hydration states have been studied for decades. However, they are still not completely understood, and discrepancies in literature are present [11-14,27].

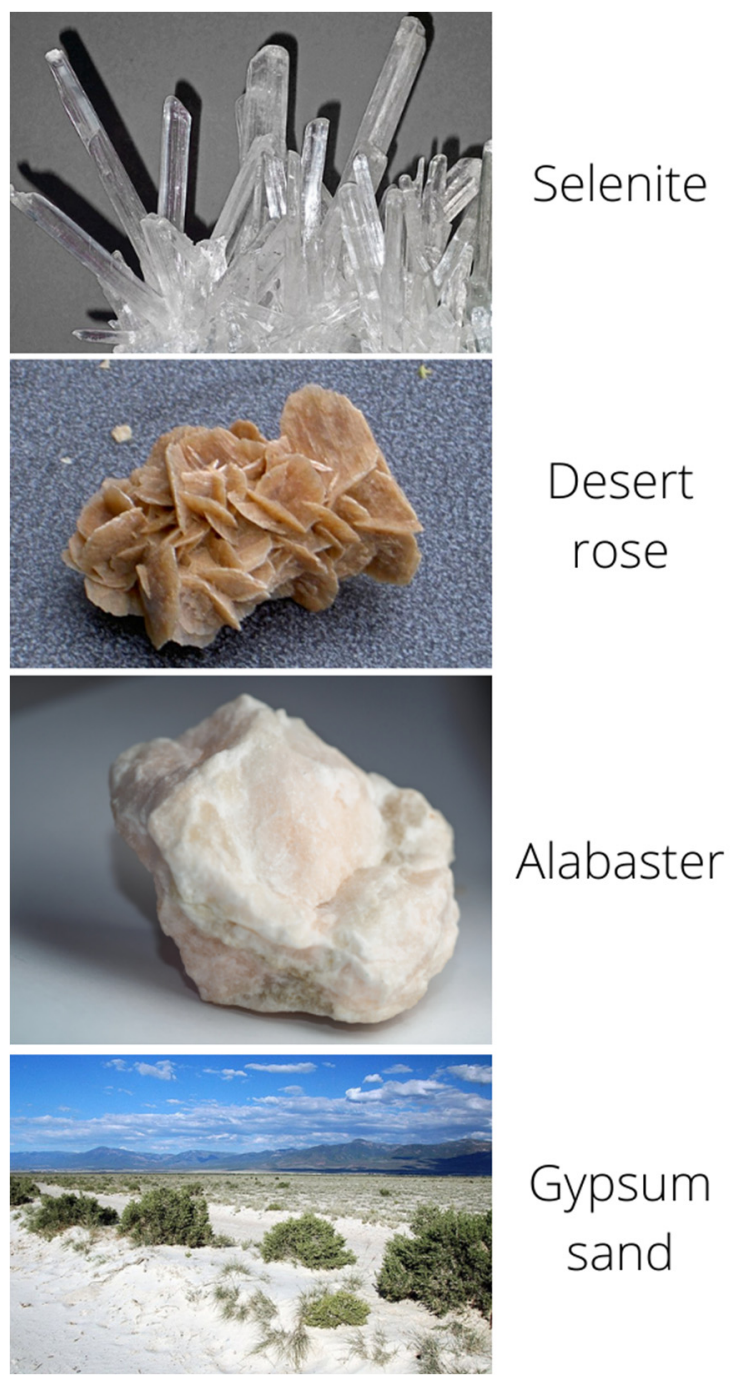

Figure 5. Different forms of calcium sulfate in nature. All pictures are published under a Creative Commons License https:/ / creativecommons.org/licenses/by-nc/4.0/.

Gypsum easily loses water when heated. The equilibrium of the endothermic reactions expressed in Equations (1) and (2) is displaced to decomposition by heating, while the addition of water to the hemihydrate and anhydrous compounds produces the inverse exothermic processes and forms polycrystalline hydrated gypsum.

$$
\mathrm{CaSO}_{4} \cdot 2 \mathrm{H}_{2} \mathrm{O} \leftrightarrow \mathrm{CaSO}_{4} \cdot 0.5 \mathrm{H}_{2} \mathrm{O}+1.5 \mathrm{H}_{2} \mathrm{O}_{(\mathrm{g})}
$$




$$
\mathrm{CaSO}_{4} \cdot 2 \mathrm{H}_{2} \mathrm{O} \leftrightarrow \mathrm{CaSO}_{4}+2 \mathrm{H}_{2} \mathrm{O}_{(\mathrm{g})}
$$

\subsection{Structure}

Although the structures of calcium sulfates portray essential differences, they are based on coordination polyhedrons that stabilize the $\mathrm{Ca}^{2+}$ ions. Each ion typically has a coordination number of eight or nine. The basic distribution of the atoms in anhydrite consists of alternating dodecahedral $\mathrm{Ca}^{2+}$ chains that share edges with tetrahedral $\mathrm{SO}^{2-}$. Bassanite and gypsum represent small variations in anhydrite's basic structure (Figure 6) [42] and, while calcium sulfate has been studied for several decades, no consensus has been reached on the balance it represents with the rest of its hydrated variants [43]. These structures have been studied with several techniques, such as neutron diffraction and synchrotron radiation [44].
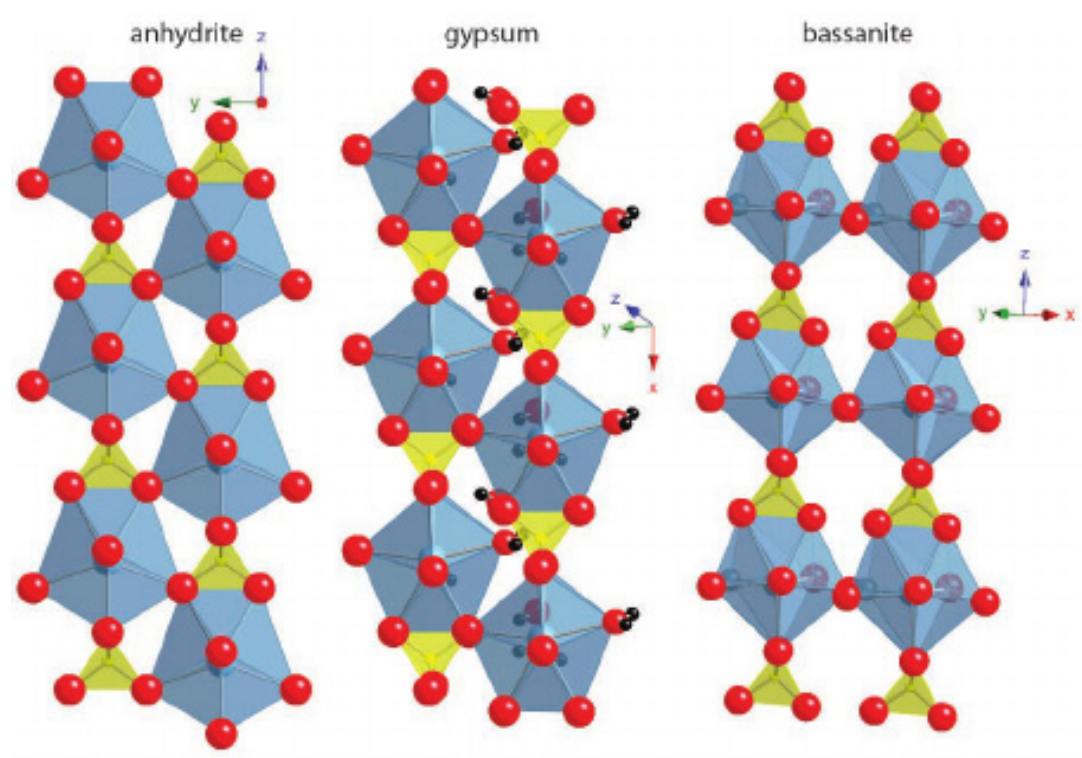

Figure 6. Anhydrite, gypsum and bassanite crystalline structures. Pictures from Janice L. Bishop et al. (2014) [42].

The gypsum structure differs from anhydrite in the distance between the chains. In the first one, it is greater and water molecules occupy a place in the octa-coordinated $\mathrm{Ca}$, which results in a layered structure linked by hydrogen bonds. In general, the compactness of $\mathrm{CaSO}_{4}$ hydrates structures depends on the amount of $\mathrm{H}_{2} \mathrm{O}$ present in the structure [45]. The energies associated with the hydration and dehydration processes have been widely studied [46].

Bassanite has two main forms, $\alpha$ and $\beta$, and both may present different lattice parameters [47]. The first is obtained by dehydrating gypsum in acidified water or hydrothermally in the presence of electrolytes. The second form is obtained by dehydrating gypsum in water vapor at temperatures above $100{ }^{\circ} \mathrm{C}$. Some authors argue that the $\alpha$ form crystallizes in a monoclinic system, while the $\beta$ form does so in a trigonal form [48], while others argue that there is no structural difference [49]. Both forms have different chemical behaviors, such as their interaction with water, as well as different chemical properties regarding their magnetic resonance patterns. It is generally accepted that bassanite consists of a $\mathrm{CaSO}_{4}$ molecule associated with $0.5 \mathrm{H}_{2} \mathrm{O}$ [50], although other types of refinements show that varieties such as $\mathrm{CaSO}_{4} \cdot 0.6 \mathrm{H}_{2} \mathrm{O}[51]$ or even $\mathrm{CaSO}_{4} \cdot 0.81 \mathrm{H}_{2} \mathrm{O}$ [52] can be formed with relative frequency.

As a rule, $\mathrm{CaSO}_{4} \cdot 0.5 \mathrm{H}_{2} \mathrm{O}$ crystallizes in a hexagonal prism form, which is topped by rhombohedral faces, although epitaxy on a gypsum substrate is relatively standard. In such cases, bassanite growths on the $(1,0,0)$ and $(0,1,0)$ faces of gypsum, maintaining the direction of the $\mathrm{Ca}^{2+}$ and $\mathrm{SO}_{4}{ }^{2-}$ chains [53]. On the other hand, calcium sulfate dihydrate crystals 
$\left(\mathrm{CaSO}_{4} \cdot 2 \mathrm{H}_{2} \mathrm{O}\right)$ are organized in monoclinic crystalline networks, which form exfoliable, low-hardness layers with a $2.3 \mathrm{~g} / \mathrm{cm}^{3}$ density.

\subsection{Nucleation and Growth}

Naica's selenite giant crystals nucleated at low supersaturations, so the number of crystals produced in this system depends on the nucleation rate and the time the system remains in supersaturation $[13,31,53,54]$. According to the classical nucleation theory, the formation of nuclei is a one-step process that produces a nanoparticle with the same characteristics as the macroscopic crystal $[55,56]$. The nucleation rate depends on interfacial energy $(\sigma)$, molecular volume $\left(V_{m}\right)$, saturation state $(\Omega)$, and temperature $(T)$ and is given by:

$$
J s=A \cdot e\left\{-\frac{\beta V_{m}^{2} \sigma^{3} N_{A} f(\theta)}{(R T)^{3} \ln ^{2} \Omega}\right\}
$$

where $A$ is a pre-exponential rate coefficient, $\beta$ is a geometry factor, $N_{\mathrm{A}}$ is Avogadro's number, $f(\theta)$ is a correction factor for heterogeneous nucleation, and $R$ is the gas constant. Recent works [54] indicate that the classical approach to nucleation is not enough to explain the evolution of the Naica crystals, as gypsum growth involves one or more intermediate phases that interconvert over time (Figure 7). This multi-stage approach is also denoted as "non-classical nucleation", and there is no mathematical framework that satisfies all observations [57]. Different approaches have been proposed to deal with the problem of gypsum nucleation; from an induction time perspective, based on predictions from the classical nucleation theory and experimental observations [58], to a coupled model of basic crystal growth and nucleation rate laws [59].

Prior to nucleation, rod-shaped gypsum clusters are formed, with an anhydrous core and only surface water molecules. These structures are the precursor of larger gypsum crystals [60]. Due to the thermodynamic balance that the system must keep, the nucleation is highly unlikely for low supersaturation values. As these values increase, the probability of nucleation grows rapidly. The nucleation rate necessary to generate these crystals is narrowly close to the precipitation conditions. Outside this region, there would not be any precipitation at all, or massive precipitation would happen, so we can conclude that the growth of these crystals is highly unlikely.

In the end, there is not a single pathway to gypsum growth, and an integration of a non-classical nucleation, at the nanoscale, and a classical nucleation approach is required to understand gypsum development $[11,61-66]$. This synergy is suggested by the use of synchrotron-based techniques. They allow studying calcium sulfate (and other minerals) nucleation at low supersaturation, enabling to experimentally confirm a multistep process [67]. The kinetically most accessible pathway will prevail depending on physicochemical conditions [68], which can lead to massive evaporite deposits or crystalline structures [61]. Van Driessche [11] has studied different forms of bassanite, as nanorods or nanoparticles, produced from vacuum/solvent filtration or cryo-quenching techniques, as seen in Figure 8.

After nucleation, selenite crystals start to grow according to the mechanism proposed by García-Ruiz. This mechanism involves a low concentration solution with an isotopic composition compatible with a sulfate from the mine's native anhydrite solution. His team started from three different saline concentrations and was able to establish the kinetics balance of the gypsum crystals, concluding that these required more than a million years at a temperature of $54^{\circ} \mathrm{C}$, to be able to grow to the size in which they are currently found in the "Cueva de los cristales" [31]. The combination of unusual geological conditions resulted in a self-sustained mechanism based on a solution with slow and smooth anhydrite-selenite phase transitions [55]. Conditions in the early stages of nucleation could imprint critical structural features at larger scales [69]. 


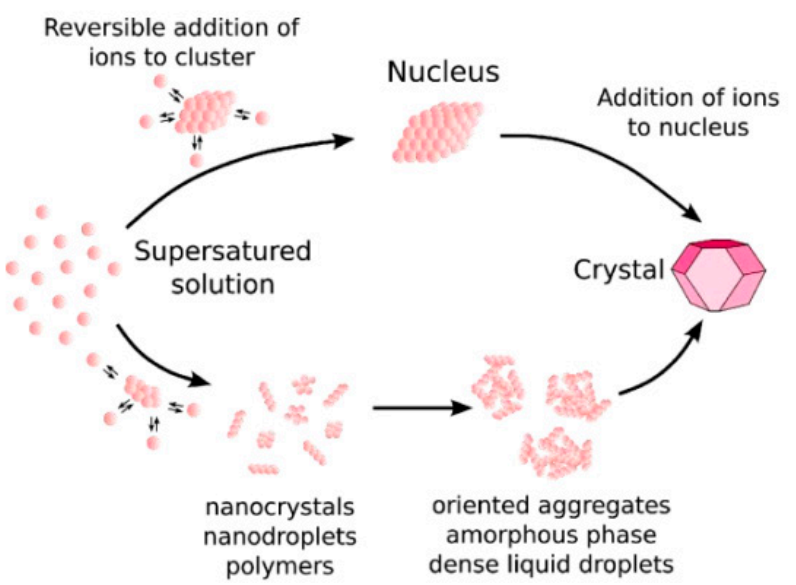

(a)

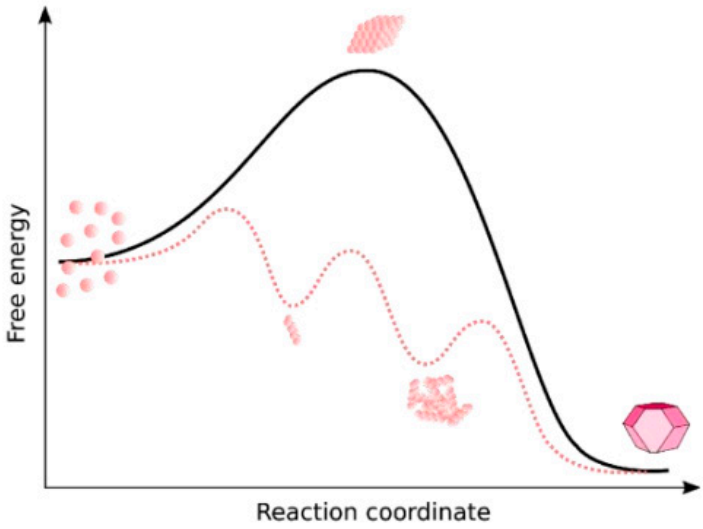

(b)

Figure 7. (a) Possible pathways for crystal growth according to a classical (upper) and non-classical (lower) theory. (b) Associated energies for a one-step process (solid line) and a multi-step process (dotted line). Figure from Van Driessche et al. (2019) [69].
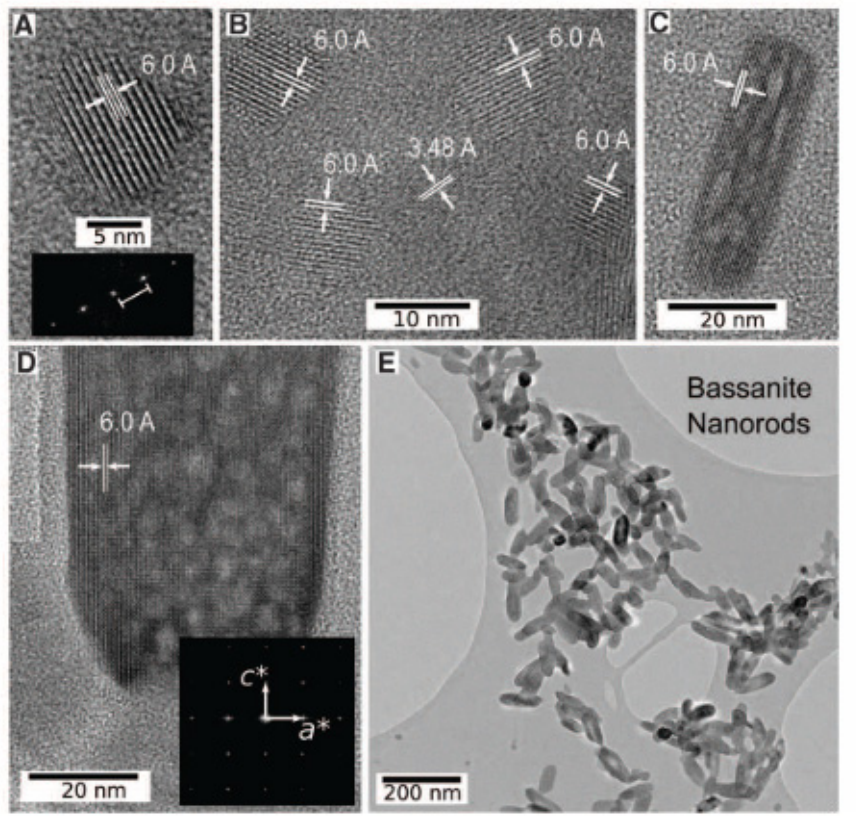
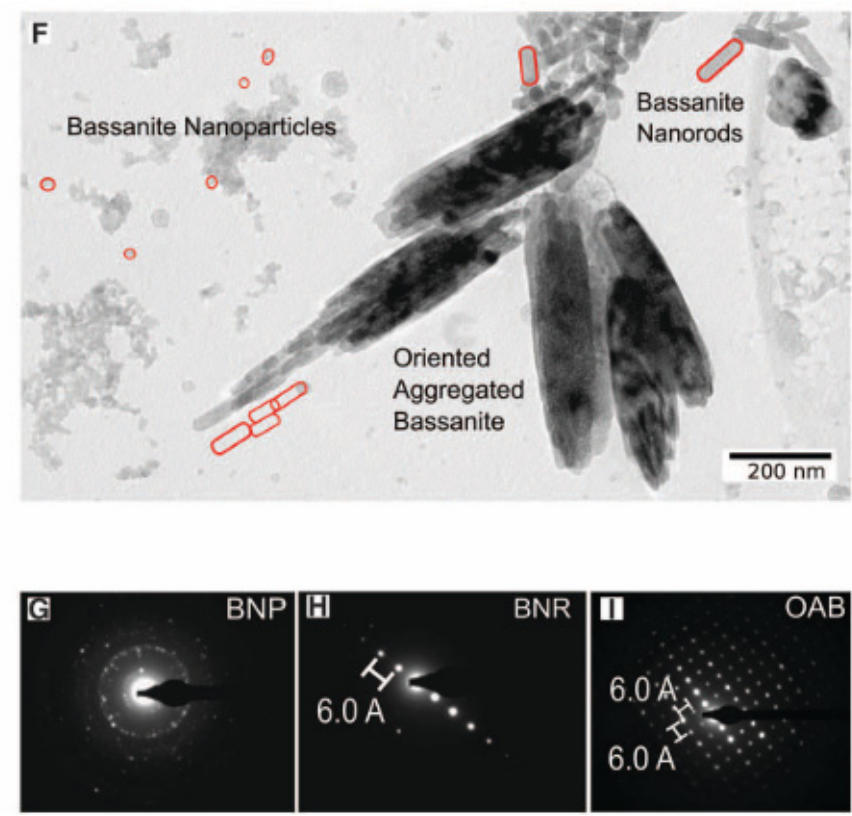

Figure 8. High Resolution Transmission Electron Microscopy (HR-TEM) microphotographs from the bassanite growth via vacuum/solvent filtration and cryo-quenching. (A) Typical bassanite particle. (B) Set of bassanite nanoparticles with representative 6.0 and $3.48 \AA$ d-spacings. (C) small and (D) large bassanite nanorods. (E) Bassanite nanorods oriented prior to aggregation. (F) Bassanite nanorods and coexisting nanoparticles. Areas selected for electron diffraction (G), bassanite nanorods with reciprocal lattice in c-axis $(\mathbf{H})$, and aggregated bassanite with reciprocal lattice along $\mathrm{c}$ and a axes (I). Figure from Van Driessche et al. (2012) [11]. BNP = Bassanite nanoparticles; BNR = Bassanite nanorods; OAB = Oriented aggregated bassanite.

As seen in Figure 8F, several bassanite morphologies can coexist in specific conditions. Self-assembly bassanite nanorod aggregates lead to micrometer-sized gypsum crystals, as seen in Figure 9, and then to a larger crystal with some bassanite remanets. 


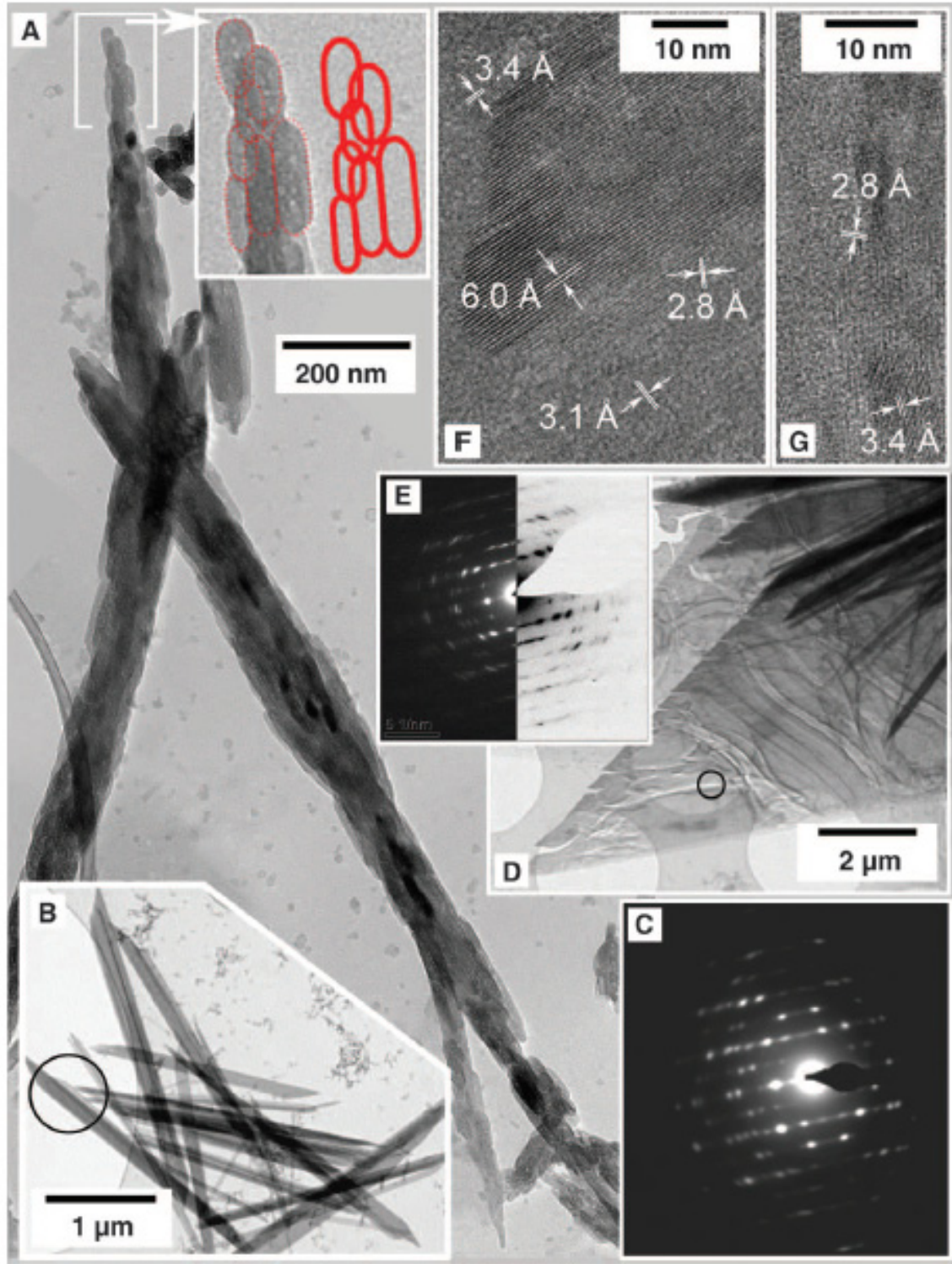

Figure 9. Gypsum crystallization. (A) A large, oriented aggregate of bassanite nanorods. (B-E) Gypsum crystals: C corresponds to the area marked in B, E corresponds to the area marked in D. $(\mathbf{F}, \mathbf{G})$ are high-resolution images of D for characteristic distances of bassanite $(6.0,3.4$, and $3.1 \AA$ ) and gypsum (3.1 and 2.8 A). Figure from Van Driessche et al. (2012) [11].

There is no consensus on the temperature equilibrium of the gypsum-anhydrite system, which can go from $47^{\circ} \mathrm{C}$, through $53{ }^{\circ} \mathrm{C}$ [70] and even reach $58{ }^{\circ} \mathrm{C}$ [71]. Fluid inclusions from different caves have been used to calculate gypsum growth temperatures demonstrating that growth occurred at different temperatures but within the reported range reported in the literature [72]. For the mechanism to be viable, the system must meet two requirements; there must be enough anhydrite in the area, and the solution temperature must be close, but lower, than the transition temperature of the gypsum-anhydrite system (Figure 10). Both conditions were met in Naica according to the information obtained from the liquid inclusions found in the crystals [36]. Dating using uranium, and other radioactive isotopes suggests, although the development of the crystals was uninterrupted, the crystal growth rate might have changed through time [30,73]. 


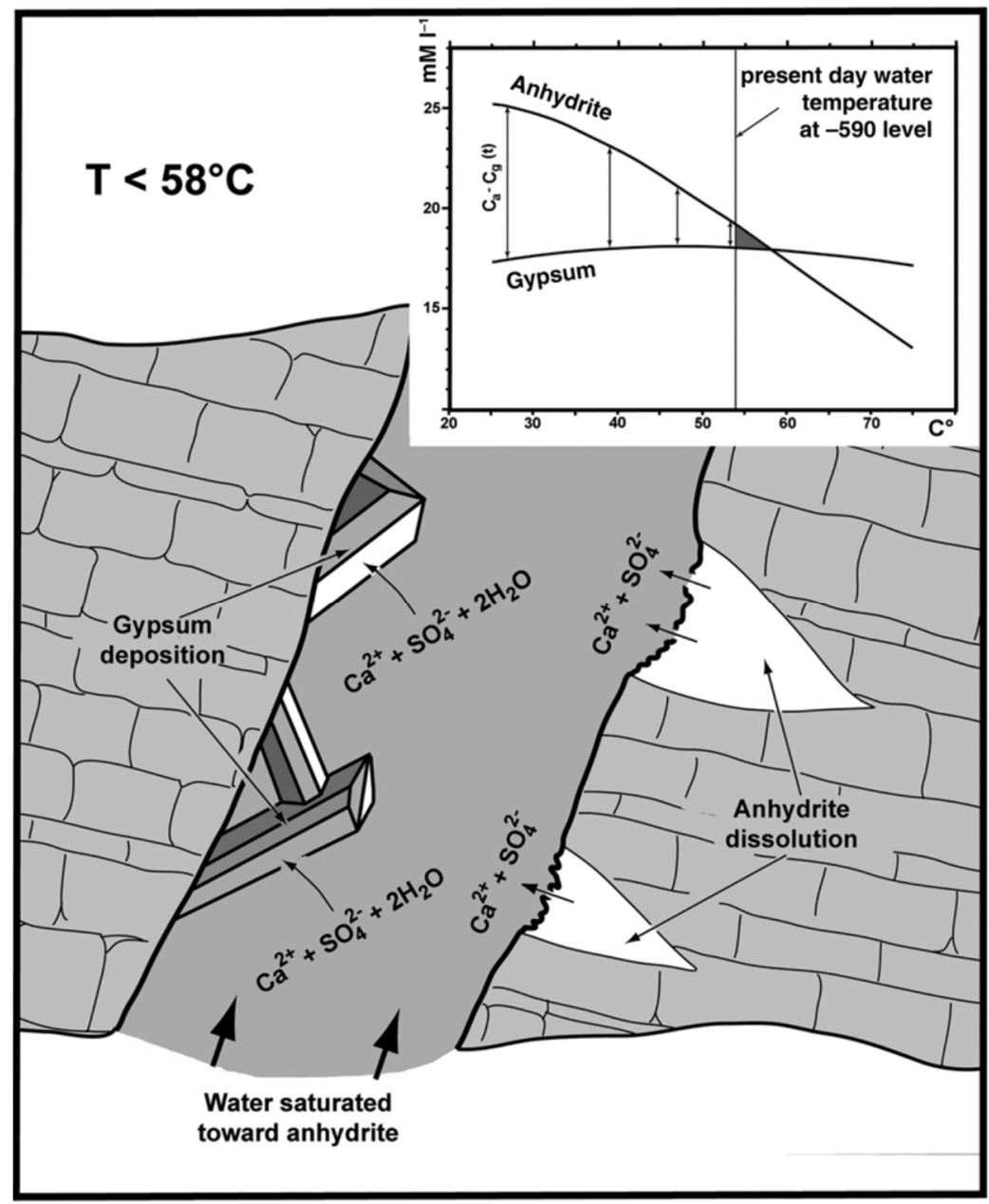

Figure 10. Anhydrite-gypsum relationship in a supersaturated solution (from Forti 2017, fig. 6).

The crystals' isotopic composition shows that the waters in which they grew came from different sources: water enriched with sulfate ions from the anhydrite solution, water from mineral deposits, and water from higher levels. This complements the theory of a complex self-regulated mechanism [43].

\section{About Research in Naica}

\subsection{Multidisciplinary Research}

Naica caves have been a passionate topic since their discovery last century. Several groups around the world have contributed to the study of their crystals through constant quality investigation. Research has been relatively robust with in situ and ex situ, experimental approaches $[18,27,31,34,36,38]$. In Figure 11, the unique proportions of the giant crystals can be observed.

Selenite is translucid and stable in standard conditions. However, nowadays, different phenomena can challenge its stability. From carbon dioxide $\left(\mathrm{CO}_{2}\right)$ effects [74], crystal structure [75] and surface impurities characterization [76], the role of microclimatic conditions $[77,78]$ and microbial diversity $[35,39,40]$, to speleothems formation $[34,38]$. Conservation and protection against degradation is a relevant issue discussed by several authors. Some ideas have been proposed, from strict regulation to potential visitors to an ex-situ exposition [79]. Nevertheless, for the crystals, the eventual flood of the caves is the best scenario [80]. Naica's research cycle has been intense over the last two decades, comprising the origin of the giant crystals as well as its mineralogy, geochemistry, and microclimatology [81]. 


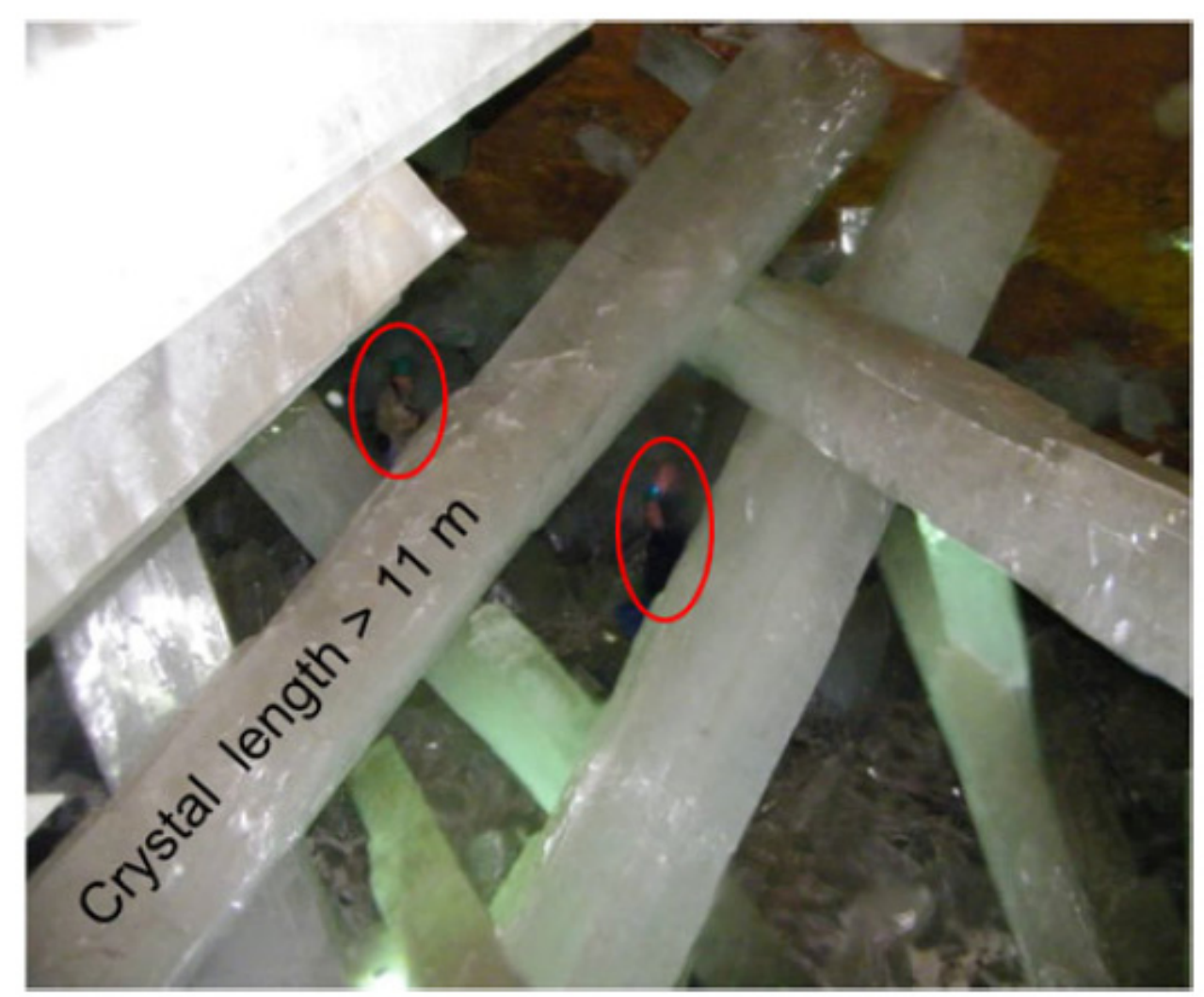

Figure 11. Giant gypsum crystals size compared to human size (encircled in red). Taken from Montero-Cabrera et al. (2020).

Mining was a constant activity during several decades in Naica's complex. Constant exploration and excavation likely produced unusual amounts of carbon oxides (COx), nitrogen oxides (NOx), sulphur oxides (SOx), among other gases. CarreñoMárquez et al. [74] studied, with detail, carbon dioxide $\left(\mathrm{CO}_{2}\right)$ effect. They reproduced some plausible environmental conditions in a customized climate fog chamber with intermittent conditions, simulating the effect of people entering and leaving "Cueva de los cristales", as it was the norm for several years. No evidence of calcium carbonate formation due to the $\mathrm{CO}_{2}$ effect was found. Nevertheless, other natural causes may produce carbonate precipitation before and after water extraction [31,34]. Several phases like aragonite, hematite, galena, cuprite, and sphalerite were identified, but the origin of those was natural (non-anthropogenic) [27,31,34,36,76].

After the study of more than 40 samples with X-ray based techniques by CastilloSandoval et al. [82], the elemental and structural composition of the impurities were identified, as seen in Figure 12; concluding that when the gypsum supersaturated solution equilibrium came to an end, impurities started to accumulate on the crystal's surface. The most frequent elements identified on the impurities are $\mathrm{Ti}, \mathrm{Mn}, \mathrm{Fe}, \mathrm{Cu}, \mathrm{Zn}$, $\mathrm{As}$, and $\mathrm{Pb}$, as well as hematite, goethite, and $\mathrm{Pb}-\mathrm{Mn}$ oxides [35,75]. 

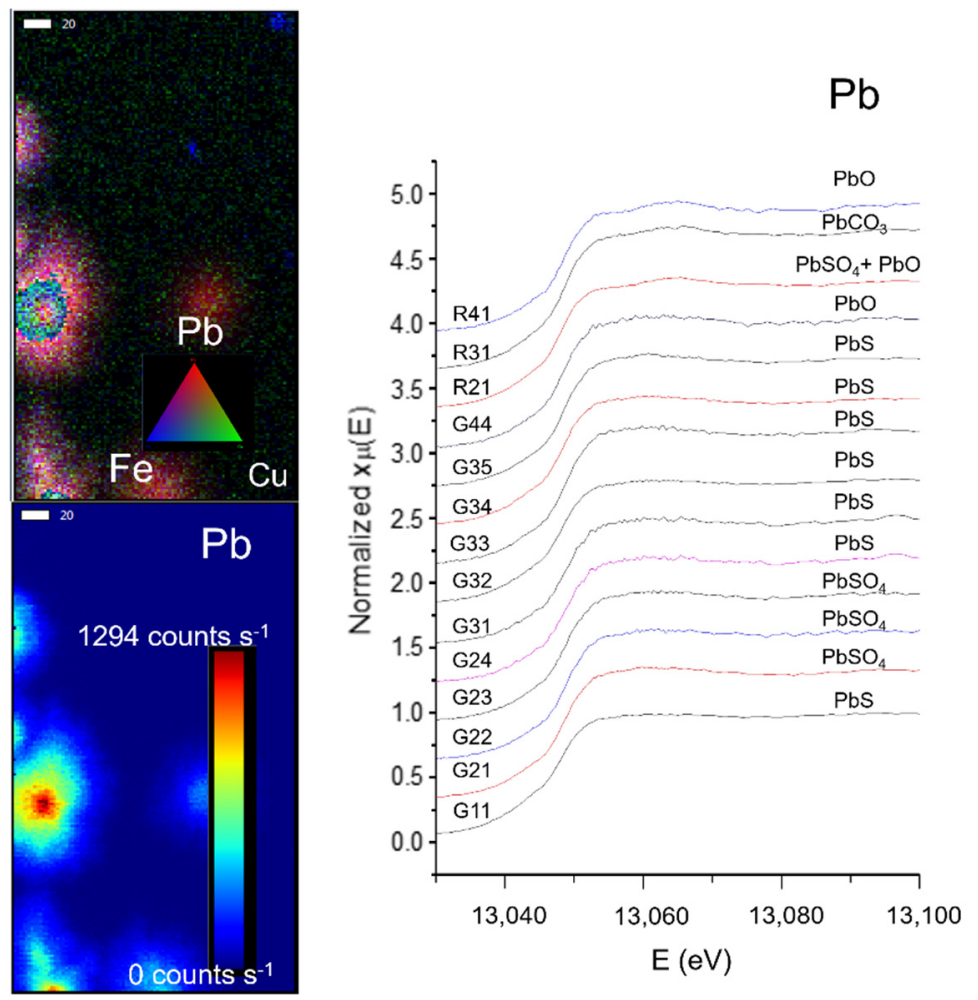

Figure 12. (Left) Micro X-ray Fluorescence ( $\mu$-XRF) elemental mapping of impurities from a selected zone on a gypsum sample, and distribution of $\mathrm{Pb}$ according to a rainbow scale of intensity. (Right) $\mu$-XANES spectra of the Pb L3 edge from 14 different ROIs in four different samples. Each spectrum shows the identification of a lead compound. Data were acquired at the SSRL BL2-3. Scale bar: $20 \mu \mathrm{m}$. Figure modified from Castillo-Sandoval et al. (2015) [75].

Due to the size and interconnections of the different galleries, temperature oscillations are normal within Naica. Air exchange and heat irradiation are causes of a particular micrometeorology [83]. Constant microclimatic fluctuations may trigger a chain of events that include surface alterations via a dehydration process and surface damage, as seen in Figure 13. Conditions like temperature $\left(25\right.$ or $\left.60^{\circ} \mathrm{C}\right)$, exposure time $(1,3,6$, or 12 months) and environment (liquid or gas) were tested in a steady-state microclimatic simulation [76] Bassanite was identified by mid-infrared spectroscopy as a first approach. Later, these samples containing bassanite were analyzed with Grazing Incidence X-ray Diffraction (GI-XRD) from laboratory and synchrotron sources, and then compared to corroborate the appearance of a new phase. In Figure 14, the signals from different spots of the same sample show the presence of gypsum and bassanite in different crystallographic planes. A semi-quantitative statistical analysis showed that (1) in short simulation times, physical damage is more relevant than any chemical transformation; (2) in long simulation times, surface alterations tend to disappear due to a dissolution/crystallization process; and (3) bassanite presence is a result of gypsum dehydration in a gaseous environment-precisely the condition taking place right now in the different caves of Naica. It has been observed that condensation/dissolution produces secondary minerals related to the fluid inclusions trapped inside the gypsum crystals [84]. 


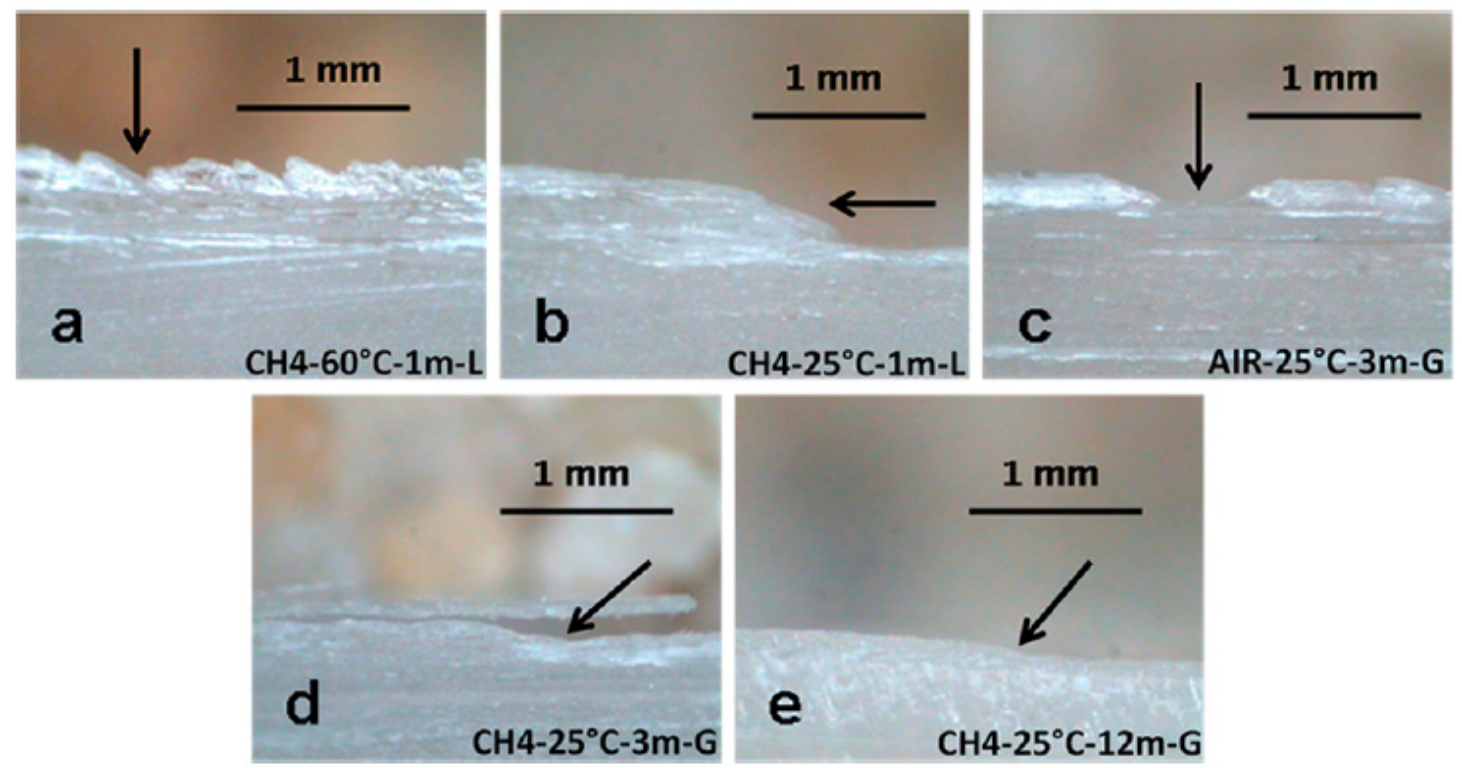

Figure 13. Structural damage detected in microclimatic simulations by Carreño-Márquez et al. (2018) [77]. Further permissions related to this figure should be directed to the American Chemical Society (ACS). (a) Irregular surface; (b) Slope; (c) Well; (d) Detachment; (e) Minor slope

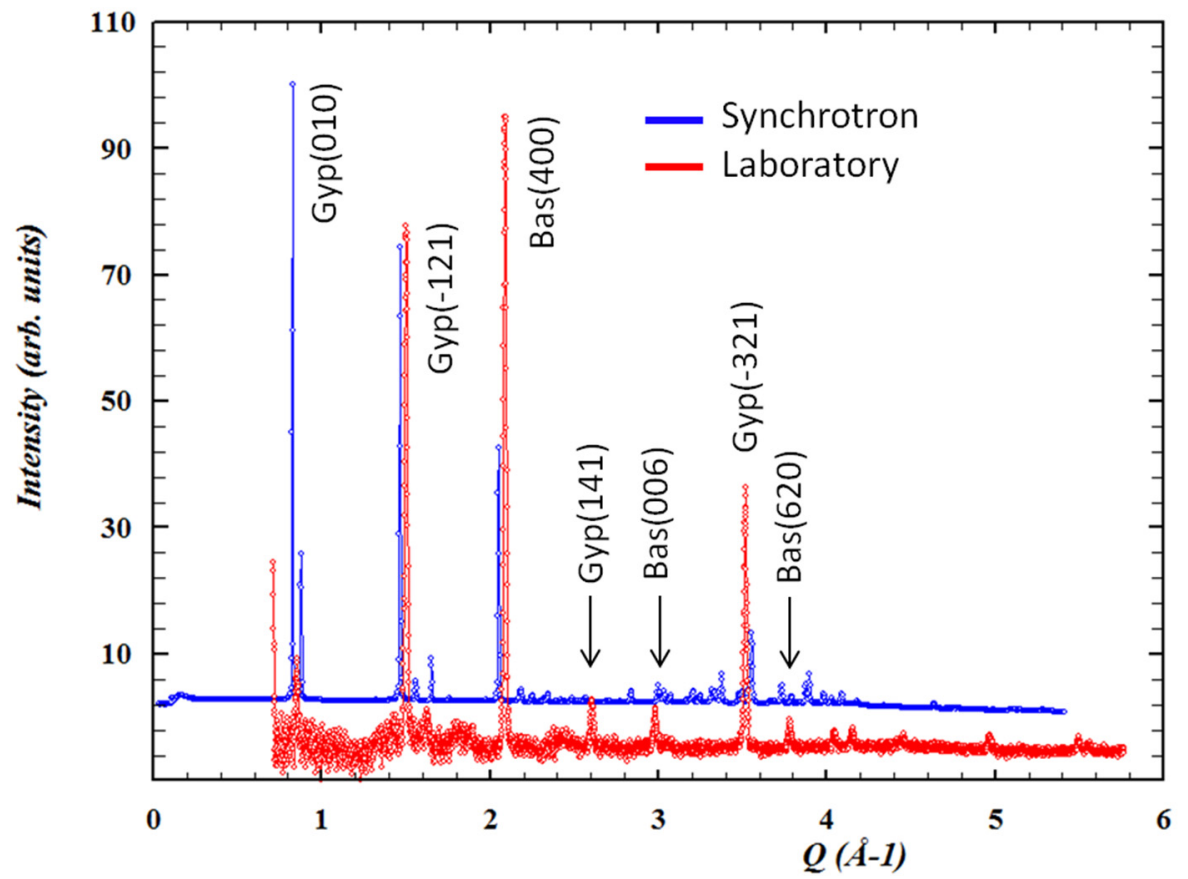

Figure 14. Conventional and synchrotron Grazing Incidence X-ray Diffraction (GI-XRD) patterns with identified gypsum and bassanite peaks. Figure from Carreño-Márquez et al. (2018) [77]. Further permissions related to this figure should be directed to the ACS. Gyp = Gypsum; Bas = Bassanite

Montero-Cabrera and her team have studied more than 70 individual Naica samples provided by private collectors, universities, and museums performing chemical and structural characterizations. The first explorations of the samples were made by visual and optical methods. After determining the most affected regions in the samples, different characterization techniques were used, including petrography, electron microscopy, and laboratory $X$-ray diffraction. They were combined with synchrotron radiation-based techniques, such as 2D Grazing Incidence X-ray Diffraction (GI-XRD), performed at Stanford Synchrotron Research Lightsource (SSRL) (SLAC National Accelerator Laboratory, Menlo Park, CA, 
USA); and $\mu$-XRF, and $\mu$-X-ray absorption near-edge structure ( $\mu$-XANES) measurements at Elettra-Sincrotone Trieste (Trieste, Italy) and at the European Synchrotron Radiation Facility (ESRF) (Grenoble, France). The microclimatic simulation was performed in Instituto de Ciencias de la Construcción Eduardo Torroja in Madrid, Spain, and proved to be an efficient approach to understand the dynamics of the giant gypsum crystals deterioration.

In the considered study, it has been concluded that the main impurities producing opacity in the crystals are hematite $\left(\mathrm{Fe}_{2} \mathrm{O}_{3}\right)$, sphalerite $(\mathrm{ZnS}), \gamma-\mathrm{MnO}_{2}$, galena (PbS), as well as $\mathrm{Pb}$ oxides. Nevertheless, microclimatic conditions, especially in the gaseous environment, can accelerate the crystal deterioration via dehydration of the crystal's surface.

The human role in Naica has consisted of pumping out water and generating a gaseous environment to allow the mining. Considering that water extraction has been constant for several decades, it is assumed that many years have passed since the giant crystals cave was filled with water. On the other hand, the current conditions have changed since the mining activity has ceased. As this review is being written, access has stopped, and therefore, the imminent risk to the crystal's integrity. New preventive measures should be taken to avoid deterioration if the activity in Naica is resumed.

\subsection{Parallelism with Pulpi Geode}

Another paradigmatic case of selenite is located in the town of Pulpí (Almeria, Spain). Since 1999, a series of images of gypsum crystals found in a geode began to circulate publicly and, at the moment, a formal request has been filled by local authorities to declare the geode a protected area, according to local news media. With an approximate volume of $11 \mathrm{~m}^{3}$, it contains several selenite crystals of just over a meter (Figure 15) [85].

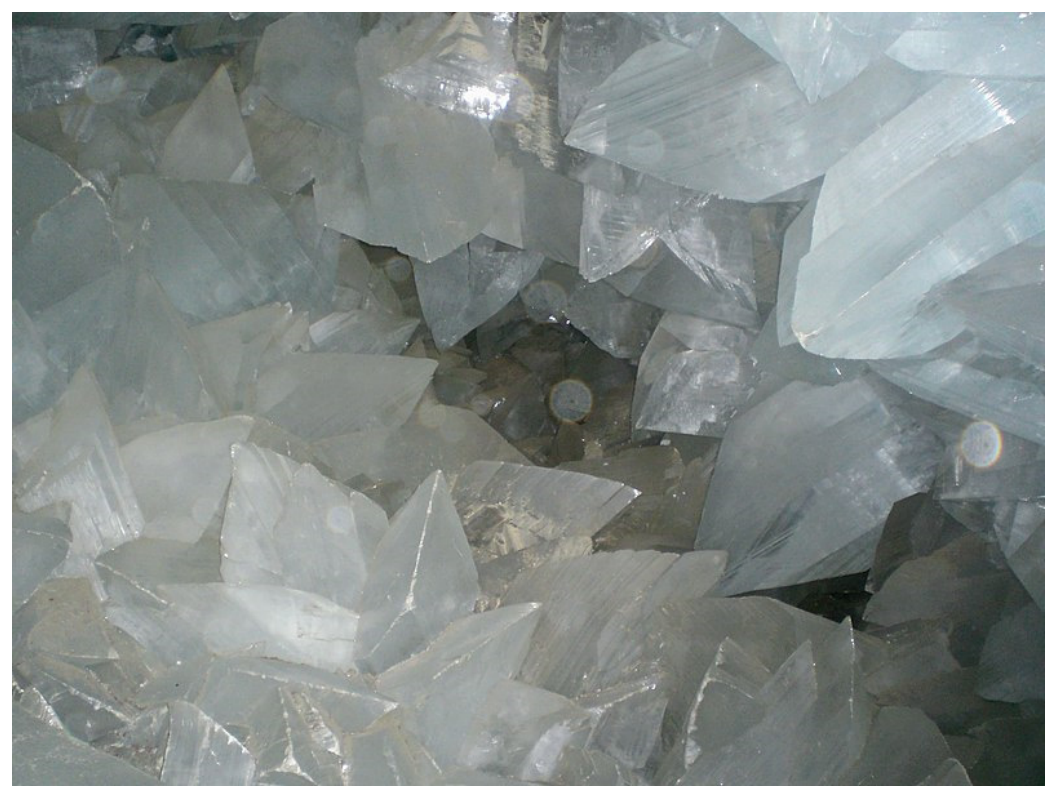

Figure 15. Interior of Pulpí geode. The average crystal size is $0.5 \mathrm{~m} \times 0.4 \mathrm{~m} \times 0.3 \mathrm{~m}$. Photo published under a Creative Commons License https://creativecommons.org/licenses/by-nc/4.0/.

The geode is located $50 \mathrm{~m}$ under the surface, at a $3 \mathrm{~km}$ distance from the sea. Some studies on the topic of the geode's genesis propose that its growth occurred in several stages: (I) the cavity formation by the removal of soluble materials; (II) the deposition of fine celestine needles on the geode walls; and (III) the subsequent infiltration of a mixture of meteoric and seawater that mixed with hydrothermal fluids, providing gradual cooling cycles $[86,87]$. Clearly, there is a parallelism with Naica. Although physicochemical conditions in Naica and Pulpí were different, conservation measures and experiences can be useful to protect Naica giant crystals. 


\section{Final Remarks}

An overview of the physicochemical investigations on the giant Naica crystals has been presented, with a particular focus on the processes that have given rise to their current appearance. The growth process that has led to the sizes and shapes of the investigated crystals has been governed by classical nucleation and growth events, combined with multi-stage variations with respect to the classical model, of the type described by Van Driessche et al. [11]. Regarding the darkening events observed in some crystals, the work by Castillo et al. [76] shows the non-anthropogenic origin of the different compounds that give rise to opacity. The influence of the presence of man in the Naica caves has been detrimental due to the subtraction of samples and for having altered the original humidity of the environment. Carreño et al. [77] have clarified that this environmental alteration feasibly generates gypsum-basanite transformations in some crystals.

Cave development is a complex phenomenon that involves several physicochemical processes over geological time, which may lead to different mineral formations. Results of the type considered in the current review provide valuable information about our planet's dynamics that can help implement conservation and preservation policies and techniques [88].

As these formations are considered a natural heritage, there are remarkable efforts to evaluate risks and prevent damage of mineral specimens [89]. Preservation endeavors must be implemented in Naica as well. Understanding the composition and effect of the climatic environments [90], and the analysis of different scenarios of people affluence [91] should advance this purpose.

Considering the current state of the giant crystals, the most viable option to approach them to the public is via an ex situ exhibition of a specimen, or the development of a virtual tour that compensates the desire to enter the caves. If the decision-makers promote visitors' accessibility, it is recommended to limit their number and contemplate additional safety measures (to both humans and crystals). To continually measure changes in physical and chemical conditions is also advised.

Author Contributions: Conceptualization, I.J.A.C.-M. and M.E.M.-C.; Writing, reviewing and editing, I.J.A.C.-M., I.C.-S., B.E.P.-C., L.E.F.-C., H.E.E.-P., E.M.-M., M.E.F.-M. and M.E.M.-C. All authors have read and agreed to the published version of the manuscript.

Funding: This research received no external funding.

Institutional Review Board Statement: Not applicable.

Informed Consent Statement: Not applicable.

Data Availability Statement: Not applicable.

Acknowledgments: The support provided by CONACYT Project No. 183706, the proposals SSRL 3939, the ESRF HG-77, Elettra Sincrotrone-Trieste 20155328, as well as by the International Centre for Theoretical Physics (ICTP) are acknowledged. Special thanks to Manuel Reyes-Cortés, who provided some of the key research samples and supported their selection and analysis. The authors thank the cooperation of the management of the Peñoles company, the Desert Museum of Ciudad Delicias, Chihuahua, the Harvard Museum of Natural History, and the Faculty of Engineering of the Autonomous University of Chihuahua for providing essential specimens for the study. The authors thank the anonymous referees for their helpful suggestions.

Conflicts of Interest: The authors declare no conflict of interest.

\section{References}

1. Rickwood, P. The largest crystals. Am. Mineral. 1981, 66, 885-907.

2. Bromehead, C.E.N. The forgotten uses of selenite. J. Mineral. Soc. 1943, 182, 325-333. [CrossRef]

3. Szynkiewicz, A.; Ewing, R.C.; Moore, C.H.; Glamoclija, M.; Bustos, D.; Pratt, L.M. Origin of terrestrial gypsum dunesImplications for Martian gypsum-rich dunes of Olympia Undae. Geomorphology 2010, 121, 69-83. [CrossRef]

4. Zambonini, F. Mineralogia Vesuviana. In Memorie della Accademia delle Scienze; Reale Accademia delle Scienze Fisiche e Matematiche di Napoli: Napoli, Italy, 1910; Volume 14, pp. 327-328. 
5. Murchie, S.L.; Seelos, F.P.; Hash, C.D.; Humm, D.C.; Malaret, E.; McGovern, J.A.; Choo, T.H.; Seelos, K.D.; Buczkowski, D.L.; Morgan, M.F.; et al. Compact Reconnaissance Imaging Spectrometer for Mars investigation and data set from the Mars Reconnaissance 'Orbiter's primary science phase. J. Geophys. Res. 2009, 114, E00D07. [CrossRef]

6. Bibring, J.P.; Langevin, Y.; Gendrin, A.; Gondet, B.; Poulet, F.; Berthe, M.; Drossart, P. Mars surface diversity as revealed by the OMEGA/Mars Express observations. Science 2005, 307, 1576-1581. [CrossRef]

7. Stefov, V.; Jovanovski, G.; Shoptrajanov, B.; Mincheva-Shukarova, B.; Dimitrovska, S.; Boev, B. Minerals from Macedonia V Characterization of gypsum, barite, and their synthetic analogues by FTIR and Raman spectroscopy. Geol. Maced. 2000, 14, 61-66.

8. Bernárdez-Gómez, M.; Guisado-Di Monti, J. Las referencias al lapis specularis en la Historia Natural de Plinio El Viejo. Pallas 2007, 75, 49. Available online: http:/ /www.jstor.org/stable/43606560 (accessed on 16 February 2021).

9. Skewes, M.A.; Arévalo, A.; Floody, R.; Zuyiga, P.; Stern, C.R. The giant El Teniente breccia deposit: Hypogene copper distribution and emplacement. In Integrated Methods for Discovery: Global Exploration in the Twenty-First Century; Goldfard, R.J., Nielsen, R.L., Eds.; Society of Economic Geologists, Inc.: Littleton, CO, USA, 2002; Volume 9, pp. 299-332.

10. Posnjak, E. The system CaSO4-H2O. Am. J. Sci. 1938, 235A, 247-272.

11. Van Driessche, A.E.S.; Benning, L.G.; Rodriguez-Blanco, J.D.; Ossorio, M.; Bots, P.; García-Ruiz, J.M. The Role and Implications of Bassanite as a Stable Precursor Phase to Gypsum Precipitation. Science 2012, 336, 69-72. [CrossRef] [PubMed]

12. Van Driessche, A.E.S.; García-Ruiz, J.M.; Delgado-Lopez, J.M.; Sazaki, G.; Delgado-López, J.M.; Sazaki, G.; Sazaki, G. In Situ Observation of Step Dynamics on Gypsum Crystals. Cryst. Growth Des. 2010, 10, 3909-3916. [CrossRef]

13. Van Driessche, A.E.S.; García-Ruiz, J.M.; Tsukamoto, K.; Patino-López, L.D.; Satoh, H. From the Cover: Ultraslow growth rates of giant gypsum crystals. Proc. Natl. Acad. Sci. USA 2011, 108, 15721-15726. [CrossRef] [PubMed]

14. Singh, N.B.; Middendorf, B. Calcium sulfate hemihydrate hydration leading to gypsum crystallization. Prog. Cryst. Growth Charact. Mater. 2007, 53, 57-77. [CrossRef]

15. Pironon, J.; Dubessy, J.; Sterpenich, J.; Robert, P.; Parmentier, M.; Lassin, A.; Randi, A. Dehydration of Gypsum Under Dry CO 2 Injection. Energy Procedia 2013, 37, 4575-4582. [CrossRef]

16. Stone, J.G. Ore genesis in the Naica district, Chihuahua, Mexico. Econ. Geol. 1959, 54, 1002-1034. [CrossRef]

17. Alva-Valdivia, L.M.; Goguitchaichvili, A.; Urrutia-Fucugauchi, J. Petromagnetic properties in the Naica mining district, Chihuahua, Mexico: Searching for source of mineralization. Earth Planets Space 2003, 55, 19-32. [CrossRef]

18. Erwood, R.J.; Kesler, S.E.; Cloke, P.L. Compositionally distinct, saline hydrothermal solutions, Naica mine, Chihuahua, Mexico. Econ. Geol. 1979, 74, 95-108. [CrossRef]

19. Forti, P. Genesis and evolution of the caves in the Naica Mine (Chihuahua, Mexico). Z. Für Geomorphol. 2010, 54 (Suppl. 2), 285-306. [CrossRef]

20. Marín-Herrera, B.R.; Vogel-González, F.; Echegoyén-Guzman, R. Las megaselenitas del distrito minero de Naica, Chihuahua, una ocurrencia mineralogica anomala. Boletín Mineral. 2006, 17, 139-148.

21. Briceño-Prieto, S. Caracterización Geoquímica de los Megacristales de Yeso de Naica, Chihuahua y su Relación con los Procesos de Interacción Agua-Roca. Unpublished. Master Thesis, Geology Institute, Universidad Nacional Autónoma de México, Mexico City, Mexico, 2011. Available online: https:/ /ru.dgb.unam.mx/handle/DGB_UNAM/TES01000693286 (accessed on 21 January 2021).

22. Trejo-de la Cruz, P. Origen del Agua y Exploración de Yacimientos Minerales en el Distrito Minero de Naica, Edo. de Chihuahua. Mem. Conv. Soc. Geol. Mex. 1971, 1, 273.

23. Gázquez, F.; Calaforra, J.M.; Stoll, H.; Sanna, L.; Forti, P.; Lauritzen, S.E.; Delgado, A.; Rull, F.; Martínez-Frías, J. Isotope and trace element evolution of the Naica aquifer (Chihuahua, Mexico) over the past 60,000 yr revealed by speleothems. Quat. Res. 2013, 80, 510-521. [CrossRef]

24. Giulivo, I.; Mecchia, M.; Piccini, P.; Sauro, P. Geology and hydrogeology of Naica. In Le Grotte di Naica: Esplorazione, Documentazione, Ricerca; Forti, P., Ed.; University of Bologna: Bologna, Italy, 2007; pp. 49-50.

25. De la Torre-Carlos, J.C. Acuífero del yacimiento mineral de Naica. In Memoria Convención; Asociación de Ingenieros de Minas, Metalurgistas y Geólogos de México, A.C.: Chihuahua, Mexico, 1997; Volume 22, p. 149.

26. Maya-Pacheco, R. Explotación de los Mantos: Tercero, Cuarto y Quinto con Contenidos Económicamente Aprovechables de Tungsteno y Molibdeno en la Unidad Naica, de la Compañía Minera Fresnillo, S.A. de C.V. localizada en Naica, Chihuahua. Unpublished. Bachelor's Thesis, Engineering School, University of Sonora, Hermosillo, Mexico, 1984. Available online: http: / / www.bidi.uson.mx/TesisIndice.aspx?tesis=4409 (accessed on 17 February 2021).

27. Garofalo, P.S.; Fricker, M.B.; Ganther, D.; Forti, P.; Mercuri, A.M.; Loreti, M.; Capaccioni, B. Climatic control on the growth of gigantic gypsum crystals within hypogenic caves (Naica mine, Mexico)? Earth Planet. Sci. Lett. 2010, 289, 560-569. [CrossRef]

28. Gázquez, F.; Calaforra, J.M.; Sanna, L.; Forti, P. Espeleotemas de yeso: Un nuevo proxy paleoclimático. Bol. Real Soc. Esp. Hist. Nat. Secc. Geol. 2011, 105, 15-24.

29. Wayne, M.; Bundy, W.M. Petrology of Gypsum-Anhydrite Deposits in Southwestern Indiana. SEPM J. Sediment. Res. 1956, 26. [CrossRef]

30. Sanna, L.; Forti, P.; Lauritzen, S.E. Preliminary U-Th dating and the evolution of gypsum crystals in Naica caves (Mexico). Acta Carsol. 2011, 40, 17-28. [CrossRef]

31. García-Ruiz, J.M.; Villasuso, R.; Ayora, C.; Canals, A.; Otalora, F. The Formation of Gypsum Megacrystals. Geology 2007, 35, 327-330. [CrossRef] 
32. Wittich, E.; Pastor, A.; Giraud, A. Unos cristales gigantes de yeso procedentes de la mina Naica, Chihuahua. Boletín de la Sociedad Geológica Mexicana 1912, 81, 61-70. [CrossRef]

33. Foshag, W. The selenite caves of Naica. Am. Mineral. 1927, 12, 252-256.

34. Gázquez, F.; Calaforra, J.; Forti, P.; Rull, F.; Martínez-Frías, J. Gypsum-carbonate speleothems from Cueva de las Espadas (Naica mine, Mexico): Mineralogy and palaeohydrogeological implications. Int. J. Speleol. 2012, 41, 211-220. [CrossRef]

35. Garofalo, P.S.; Fricker, M.; Günther, D.; Forti, P.; Lauritzen, S.E.; Mercuri, A.M.; Loreti, M. A tale of precipitation and growth of giant selenite crystals within the caves of Naica (Chiuhahua, Mexico). RMS 2008, 158-159. Available online: http:/ / www.minsoc. ru/2008-1-72-1 (accessed on 21 January 2021).

36. Forti, P.; Sanna, L. The Naica Project: A multidisciplinary study of the largest gypsum crystals of the world. Episodes 2010, 33, 23-32. [CrossRef]

37. García-Ruiz, J.M.; Otálora, F. Crystal Growth in Geology: Patterns on the Rocks. In Handbook of Crystal Growth: Bulk Crystal Growth: Second Edition; Elsevier: Amsterdam, The Netherlands, 2015; Volume 2, pp. 1-43. [CrossRef]

38. Bernabei, T.; Forti, P.; Villasuso, R. Sails: A new gypsum speleothem from Naica, Chihuahua, Mexico. Int. J. Speleol. 2007, 36, 23-30. [CrossRef]

39. Espino-del Castillo, A.; Beraldi-Campesi, H.; Amador-Lemus, P.; Beltrán, H.I.; Le Borgne, S. Bacterial diversity associated with mineral substrates and hot springs from caves and tunnels of the Naica Underground System (Chihuahua, Mexico). Int. J. Speleol. 2018, 47, 213-227. [CrossRef]

40. Ragon, M.; Van Driessche, A.E.S.; Garcia-Ruiz, J.M.; Moreira, D.; Lopez-Garcia, P. Microbial diversity in the deep-subsurface hydrothermal aquifer feeding the giant gypsum crystal-bearing Naica mine, Mexico. Front. Microbiol. 2013, 4, 37. [CrossRef] [PubMed]

41. Holden, C. Life in crystal. Science 2008, 319, 391a. [CrossRef]

42. Bishop, J.; Lane, M.; Dyar, D.; King, S.; Brown, A.; Swayze, G. Ca-sulfate's spectral properties: Gypsum, bassanite, and anhydrite. Am. Mineral. 2014, 99, 2105-2115. [CrossRef]

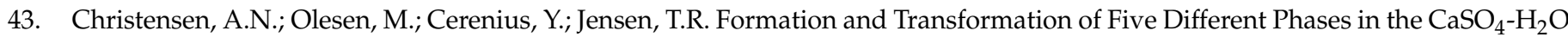
System: Crystal Structure of the Subhydrate $\beta-\mathrm{CaSO}_{4}-0.5 \mathrm{H}_{2} \mathrm{O}$ and Soluble Anhydrite $\mathrm{CaSO}_{4}$. Chem. Mater. 2008, 20, $2124-2132$. [CrossRef]

44. Van Rosmalen, G.M.; Daudey, P.J.; Marchée, W.G.J. An analysis of growth experiments of gypsum crystals in suspension. J. Cryst. Growth 1981, 52, 801-811. [CrossRef]

45. Hawthorne, F.C.; Krivovichev, S.V.; Burns, P.C. The Crystal Chemistry of Sulfate Minerals. Rev. Mineral. Geochem. 2000, 40, 1-112. [CrossRef]

46. Kuzel, H.J.; Hauner, M. Chemical and crystallographical properties of calcium sulfate hemihydrate and anhydrite III. ZKG, Zement-Kalk-Gips Edition A 1987, 40, 628-632.

47. Hildyard, R.C.; Llana-Funez, S.; Wheeler, J.; Faulkner, D.R.; Prior, D.J. Electron Backscatter Diffraction (EBSD) Analysis of Bassanite Transformation Textures and Crystal Structure Produced from Experimentally Deformed and Dehydrated Gypsum. J. Petrol. 2011, 52, 839-856. [CrossRef]

48. Ballirano, P.; Maras, A.; Meloni, S.; Caminiti, R. The monoclinic I2 structure of bassanite, calcium sulphate hemihydrate $\left(\mathrm{CaSO}_{4} \cdot 0.5 \mathrm{H}_{2} \mathrm{O}\right)$. Eur. J. Mineral. 2001, 13, 956-993. [CrossRef]

49. Bushuev, N.N.; Borisov, V.M. X-ray-diffraction study of CaSO4·0,67 $\mathrm{H}_{2}$ O. Zhurnal Neorganicheskoi Khimii 1982, $27,604-609$.

50. Gallitelli, P. Ricerche sul solfato di calcio semidrato e sull'anidrite solubile. Period. Min. Roma 1933, 4, 1-42.

51. Bezou, C.; Nonat, A.; Mutin, J.C.; Christensen, A.N.; Lehmann, M.S. Investigation of the crystal structure of $\gamma$-CaSO 4 , $\mathrm{CaSO}_{4} \cdot 0.5 \mathrm{H}_{2} \mathrm{O}$, and $\mathrm{CaSO}_{4} \cdot 0.6 \mathrm{H}_{2} \mathrm{O}$ by powder diffraction methods. J. Solid State Chem. 1995, 117, 165-176. [CrossRef]

52. Abriel, W. Calcium sulfat subhydrat, $\mathrm{CaSO}_{4}$. 0, 8 $\mathrm{H}_{2} \mathrm{O}$. Acta Crystallogr. Sect. C Cryst. Struct. Commun. 1983, 39, 956-958. [CrossRef]

53. Follner, S.; Wolter, A.; Preusser, A.; Indris, S.; Silber, C.; Follner, H. The Setting Behaviour of $\alpha-$ and $\beta-\mathrm{CaSO}_{4} \cdot 0,5 \mathrm{H}_{2} \mathrm{O}$ as a Function of Crystal Structure and Morphology. Cryst. Res. Technol. 2002, 37, 1075-1087. [CrossRef]

54. Kelley, K.K.; Southard, J.C.; Anderson, C.T. Thermodynamic Properties of Gypsum and Its Dehydration Products; US Government Printing Office: Washington, DC, USA, 1941; Volume 625, p. 71.

55. Otalora, F.; Garcia-Ruiz, J.M. Nucleation and growth of the Naica giant gypsum crystals. Chem. Soc. Rev. 2014, 43, $2013-2026$. [CrossRef]

56. Ossorio, M.; Van Driessche, A.E.S.; Pérez, P.; García-Ruiz, J.M. The gypsum-anhydrite paradox revisited. Chem. Geol. 2014, 386, 16-21. [CrossRef]

57. Barbier, E.; Coste, M.; Genin, A.; Jung, D.; Lemoine, C.; Logette, S.; Muhr, H. Simultaneous determination of nucleation and crystal growth kinetics of gypsum. Chem. Eng. Sci. 2009, 64, 363-369. [CrossRef]

58. Reiss, A.G.; Gavrieli, I.; Rosenberg, Y.O.; Reznik, I.J.; Luttge, A.; Emmanuel, S.; Ganor, J. Gypsum Precipitation under Saline Conditions: Thermodynamics, Kinetics, Morphology, and Size Distribution. Minerals 2021, 11, 141. [CrossRef]

59. Reznik, I.J.; Ganor, J.; Gruber, C.; Gavrieli, I. Towards the establishment of a general rate law for gypsum nucleation. Geochim. Cosmochim. Acta 2012, 85, 75-87. [CrossRef]

60. Rendel, P.M.; Gavrieli, I.; Wolff-Boenisch, D.; Ganor, J. Towards establishing a combined rate law of nucleation and crystal growth-The case study of gypsum precipitation. J. Cryst. Growth 2018, 485, 28-40. [CrossRef] 
61. Kashchiev, D. Nucleation; Oxford, Butterworth-Heinemann, Elsevier: Oxford, UK, 2000.

62. Vekilov, P.G. Nucleation. Cryst. Growth Des. 2010, 10, 5007-5019. [CrossRef]

63. Saha, A.; Lee, J.; Pancera, S.M.; Bräeu, M.F.; Kempter, A.; Tripathi, A.; Bose, A. New Insights into the Transformation of Calcium Sulfate Hemihydrate to Gypsum Using Time-Resolved Cryogenic Transmission Electron Microscopy. Langmuir 2012, 28, 11182-11187. [CrossRef]

64. Jones, F. Infrared investigation of barite and gypsum crystallization: Evidence for an amorphous to crystalline transition. Cryst. Eng. Comm. 2012, 14, 8374-8381. [CrossRef]

65. Ossorio, M.; Stawski, T.M.; Rodríguez-Blanco, J.D.; Sleutel, M.; García-Ruiz, J.M.; Benning, L.G.; Van Driessche, A.E.S. Physicochemical and Additive Controls on the Multistep Precipitation Pathway of Gypsum. Minerals 2017, 7, 140. [CrossRef]

66. He, K.; Nie, A.; Yuan, Y.; Ghodsi, S.M.; Song, B.; Firlar, E.; Lu, J.; Lu, Y.; Shokuhfar, T.; Megaridis, C.M.; et al. In Situ Transmission Electron Microscopy Explores a New Nanoscale Pathway for Direct Gypsum Formation in Aqueous Solution. ACS Appl. Nano Mater. 2018, 1, 5430-5440. [CrossRef]

67. Stawski, T.M.; Benning, L.G. Chapter Five-SAXS in Inorganic and Bioinspired Research. In Research Methods in Biomineralization Science; Academic Press: Cambridge, MA, USA, 2013; Volume 532, pp. 95-127. [CrossRef]

68. Stawski, T.M.; Freeman, H.M.; Van Driessche, A.E.S.; Hövelmann, J.; Besselink, R.; Wirth, R.; Benning, L.G. Particle-Mediated Nucleation Pathways Are Imprinted in the Internal Structure of Calcium Sulfate Single Crystals. Cryst. Growth Des. 2019, 7, 3714-3721. [CrossRef]

69. Van Driessche, A.E.S.; Stawski, T.M.; Kellermeier, M. Calcium sulfate precipitation pathways in natural and engineered environments. Chem. Geol. 2019, 530, 2019-119274. [CrossRef]

70. Hardie, L.A. The gypsum-anhydrite equilibrium at one atmosphere pressure. Am. Mineral. 1967, 52, $171-200$.

71. Robie, R.A.; Hemingway, B.S.; Fisher, J.R. Thermodynamic properties of minerals and related substances at $298.15 \mathrm{~K}$ and 1 Bar (105 Pascals) pressure and at higher temperatures. Geol. Surv. Bull. 1978, 1452, 1-456.

72. Krüger, Y.; García-Ruiz, J.M.; Canals, A.; Marti, D.; Frenz, M.; Van Driessche, A.E.S. Determining gypsum growth temperatures using monophase fluid inclusions-Application to the giant gypsum crystals of Naica, Mexico. Geology 2013, 41, 119-122. [CrossRef]

73. Sanna, L.; Saez, F.; Simonsen, S.; Constantin, S.; Calaforra, J.M.; Forti, P.; Lauritzen, S.E. Uranium-series dating of gypsum speleothems: Methodology and examples. Int. J. Speleol. 2010, 39, 35-46. [CrossRef]

74. Carreño-Márquez, I.J.A.; Castillo-Sandoval, I.; Esparza-Ponce, H.E.; Fuentes-Cobas, L.; Montero-Cabrera, M.E. Characterization of gypsum crystals exposed to a high CO2 concentration fog using X-ray. In Proceedings of the AIP Conference, Ciudad Juárez, Mexico, 4-6 March 2015; Volume 1671. [CrossRef]

75. Castillo-Sandoval, I.; Fuentes-Cobas, L.E.; Fuentes-Montero, M.E.; Esparza-Ponce, H.E.; Carreño-Márquez, J.; Reyes-Cortes, M.; Montero-Cabrera, M.E. Light in the Darkening on Naica Gypsum Crystals. Xi Int. Symp. Radiat. Phys. 2015, 1671, 30005-30009. [CrossRef]

76. Castillo-Sandoval, I.; Fuentes-Cobas, L.E.; Pérez-Cazares, B.E.; Esparza-Ponce, H.E.; Fuentes-Montero, M.E.; Castillo-Michel, H.; Eichert, D.; Reyes-Cortes, I.; Carreño-Márquez, I.J.; Nápoles-Duarte, J.M.; et al. Surface impurities on giant gypsum crystals from "la Cueva de las Espadas" (Cave of Swords), Naica, Mexico. Mineral. Petrol. 2018, 112. [CrossRef]

77. Carreño-Marquez, I.J.A.; Menéndez-Méndez, E.; Esparza-Ponce, H.E.; Fuentes-Cobas, L.; García-Rovés, R.; Castillo-Sandoval, I.; Luna-Porres, M.; De-Frutos-Vaquerizo, J.; Montero-Cabrera, M.E. Naica's Giant Crystals: Deterioration Scenarios. Cryst. Growth Des. 2018, 18. [CrossRef]

78. Auvray, C.; Homand, F.; Sorgi, C. The aging of gypsum in underground mines. Eng. Geol. 2004, 74, 183-196. [CrossRef]

79. Gázquez, F.; Badino, G.; Calaforra, J.M.; Forti, P. Estrategias de conservación de los cristales gigantes de yeso. In Cuevatur 2014; Calaforra, J.M., Duran, J.J., Eds.; Asociación de Cuevas Turísticas Españolas: Aracena, Spain, 2014; pp. $29-39$.

80. Forti, P. What Will Be the Future of the Giant Gypsum Crystals of Naica Mine? In Geological Society Special Publication; Geological Society of London: London, UK, 2017; Volume 1, pp. 461-475. [CrossRef]

81. Gázquez, F.; Calaforra, J.M.; Forti, P.; Badino, G. The caves of Naica: A decade of Research. Bol. Geol. Y Min. 2016, 127, 147-163.

82. Montero-Cabrera, M.E.; Carreño-Márquez, I.; Castillo-Sandoval, I.; Pérez-Cázares, B.; Fuentes-Cobas, L.E.; Esparza-Ponce, H.E.; Menéndez-Méndez, E.; Fuentes-Montero, M.E.; Castillo-Michel, H.; Eichert, D.; et al. Are the Naica giant crystals deteriorating because of human action? Powder Diffr. 2020, 35, S15-S23. [CrossRef]

83. Badino, G. The Cueva de los Cristales micrometeorology. In Proceedings of the 15th International Congress of Speleology, Kerrville, TX, USA, 19-26 July 2009; Volume 3, pp. 1407-1412.

84. Badino, G.; Calaforra, J.M.; Forti, P.; Garofalo, P.; Sanna, L. The present day genesis and evolution of cave minerals inside the Ojo de la Reina Cave (Naica Mine, Mexico). Int. J. Speleol. 2011, 40, 125-131. [CrossRef]

85. Fernández-Cortes, A.; Calaforra, J.; García-Guinea, J. The Pulpi gigantic geode (Almeria, Spain): Geology, metal pollution, microclimatology, and conservation. Environ. Geol. 2006, 50, 707-716. [CrossRef]

86. Garcia-Guinea, J.; Morales, S.; Delgado, A.; Recio, C.; Calaforra, J.M. Formation of gigantic gypsum crystals. J. Geol. Soc. 2002, 159, 347-350. [CrossRef]

87. Canals, A.; Van Driessche, A.E.S.; Palero, F.; García-Ruiz, J.M. The origin of large gypsum crystals in the Geode of Pulpí (Almería, Spain). Geology 2019, 47, 1161-1165. [CrossRef]

88. Forti, P.; Onac, B.P. Caves and mineral deposits. Zeitschrift Geomorphol. 2016, 60, 57-102. [CrossRef] 
89. Iriarte, E.; Sánchez, M.A.; Foyo, A.; Tomillo, C. Geological risk assessment for cultural heritage conservation in karstic caves. J. Cult. Herit. 2010, 11, 250-258. [CrossRef]

90. Dragovich, D.; Grose, J. Impact of tourists on carbon dioxide levels at Jenolan Caves, Australia: An examination of microclimatic constraints on tourist cave management. Geoforum 1990, 21, 111-120. [CrossRef]

91. Šebela, S.; Turk, J. Sustainable use of the Predjama Cave (Slovenia) and possible scenarios related to anticipated major increases in tourist numbers. Tour. Manag. Perspect. 2014, 10, 37-45. [CrossRef] 